\title{
Inflation, Financial Developments, and Wealth Distribution
}




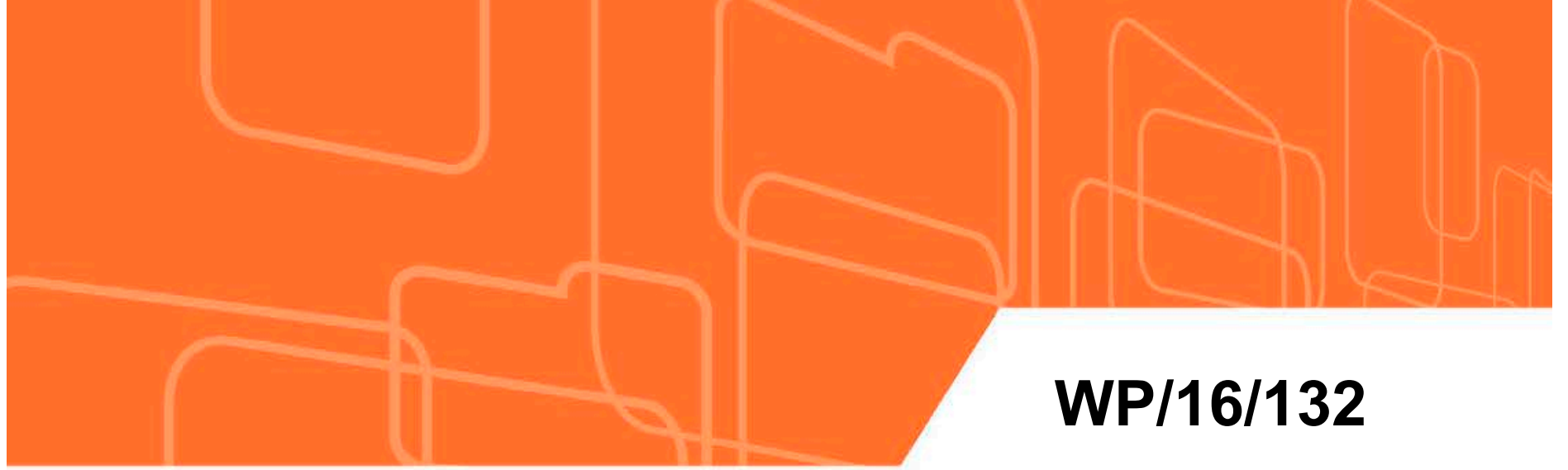

\title{
IMF Working Paper
}

Inflation, Financial Developments, and Wealth Distribution

\author{
by Wai-Yip Alex Ho and Chun-Yu Ho
}

I N T E R N A T I O N A L M O N E T A R Y F U N D 


\title{
IMF Working Paper
}

Institute for Capacity Development

\section{Inflation, Financial Developments, and Wealth Distribution ${ }^{1}$ \\ Prepared by Wai-Yip Alex Ho and Chun-Yu Ho}

Authorized for distribution by Laura Kodres

July 2016

IMF Working Papers describe research in progress by the author(s) and are published to elicit comments and to encourage debate. The views expressed in IMF Working Papers are those of the author(s) and do not necessarily represent the views of the IMF, its Executive Board, or IMF management.

\begin{abstract}
We find that from 1995 to 2002 in China, the dispersion of wealth decreased, the moneywealth ratio increased for all wealth levels and the aggregate money-output ratio increased. We develop a two-asset dynamic general equilibrium model in which households face a portfolio adjustment cost and a borrowing constraint. We find that financial development lowers the dispersion of wealth by reducing the precautionary motive of households. In addition, tight monetary policies increase the value of money and thus increase the moneywealth ratio for all wealth levels and the aggregate money-output ratio.

JEL Classification Numbers: D3, O1, O2

Keywords: Inflation, Borrowing Constraint, Adjustment Cost, Heterogeneous Agents, Wealth Distribution

Authors’ E-Mail Addresses: who@,imf.org, hezhunyu@sjtu.edu.cn

\footnotetext{
${ }^{1}$ We are deeply indebted to François Gourio, Robert G. King, Simon Gilchrist, Robert A. Margo, Robert E.B. Lucas, Laura Kodres, Andy Berg, Ling Zhu, Emine Boz. Davide Fuercei, and Marcos Poplawski, for their comments and discussions. We also thank participants from various seminars and conferences for their comments. All errors are, of course, ours.
} 


\section{Contents}

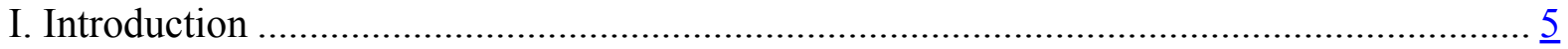

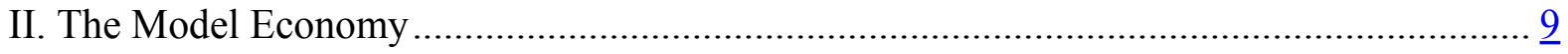

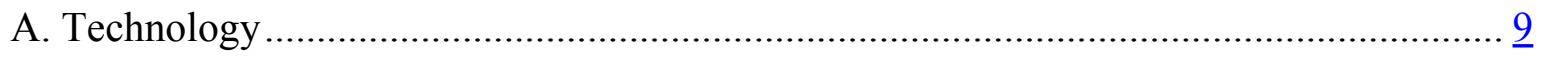

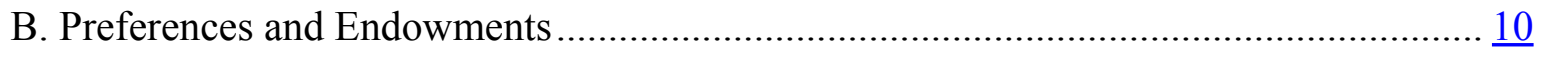

C. Market Arrangements .............................................................................. 10

D. The Dynamic Programming Problem of Households ................................................. 11

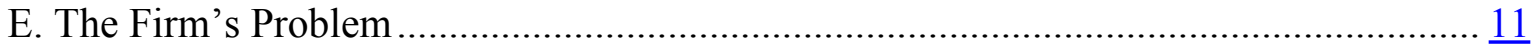

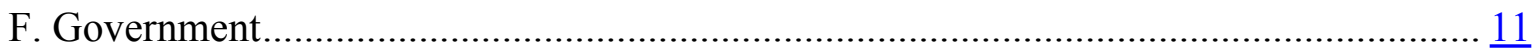

G. The Financial Institution's Problem ................................................................. 12

H. Stationary Equilibrium ................................................................................. 12

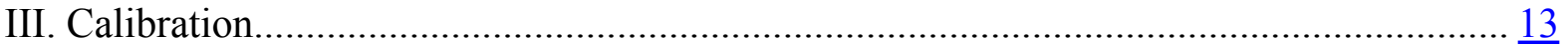

A. Micro-level Data on Income and Wealth .......................................................... 14

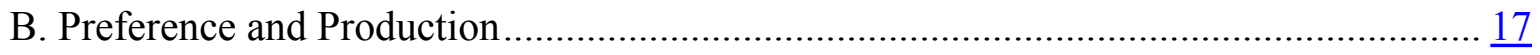

C. Monetary and Fiscal Policy ............................................................................. 17

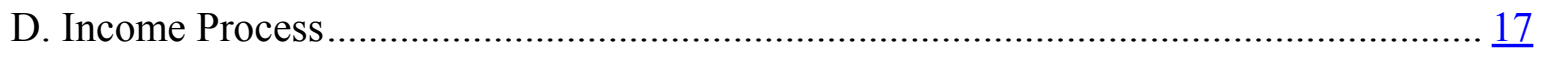

E. Financial Market Frictions .................................................................................. 20

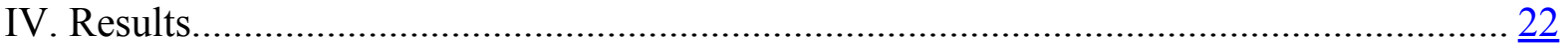

A. Benchmark Calibration......................................................................................... 23

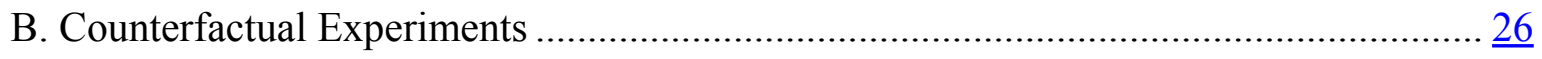

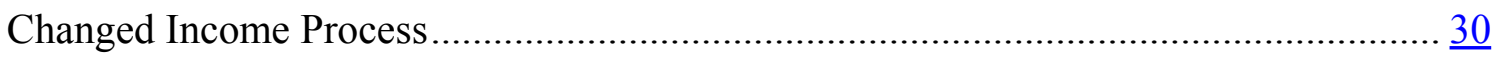

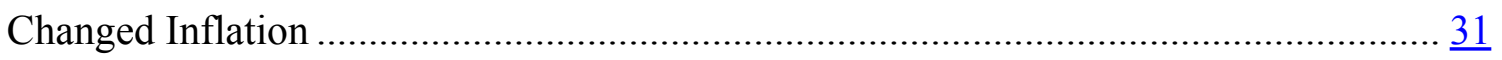

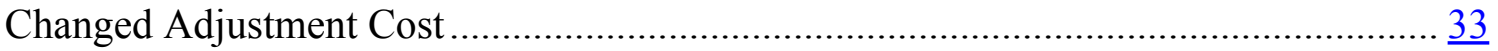

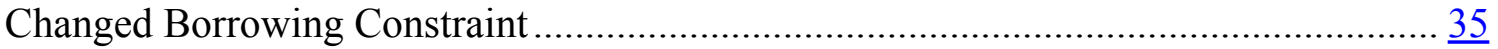

Changed Fiscal Policy ......................................................................................... 37

C. Accounting for Changes and Welfare Analysis .................................................... $\underline{39}$

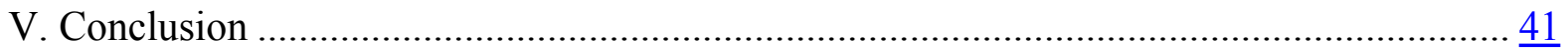

Appendix I - Computation of the model ....................................................................... 42

Appendix II- Date Description...................................................................................... 42

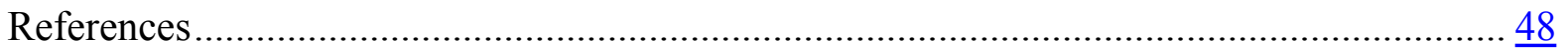

\section{List of Tables}


Table 1: Descriptive Statistics on Reported Incomes and Wealth .................................... 16

Table 2: Estimation of Income Process, CHIPS 1995 and CHIPS 2002 ............................ 19

Table 3: The transition matrix of the Discretized Income Process .................................... 20

Table 4: Calibration of parameter values of the Chinese Economy in 1995 and 2002 ......... 23

Table 5: Key macroeconomic statistic based on model under benchmark calibration and data

Table 6: Counter-Factual Experiments --- Effect at the aggregate level ............................ 27

Table 7: Counterfactual Experiments --- Effect on wealth distributions ............................. 29

Table 8: Accounting changes from 1995 to 2002 ............................................................. 40

Table A1: Households Characteristics........................................................................ 43

Table A2: Descriptive Statistics on reported incomes: CHIPS 1995 and CHIPS 2002 ........ 44

Table A3: Descriptive Statistics on Wealth distribution in 1995 and 2002 ........................ 45

\section{List of Figures}

Figure 1: The wealth distribution and Lorenz Curve, 1995 Calibrated Economy Vs 2002

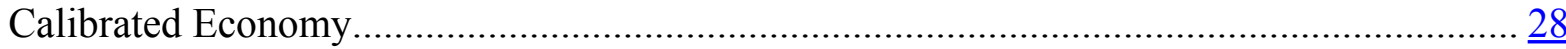

Figure 2: Financial assets holding and money holding against level of wealth of households, 1995 Calibrated Economy vs 2002 Calibrated Economy

Figure 3: The wealth distribution and Lorenz Curve, 1995 Calibrated Economy vs Changed

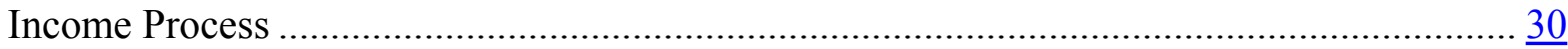

Figure 4: Financial assets holding and money holding against level of wealth of households, 1995 Calibrated Economy vs Changed Income Process................................................... 31

Figure 5: The wealth distribution and Lorenz Curve, 1995 Calibrated Economy vs Changed Inflation.....

Figure 6: Financial assets holding and money holding against level of wealth of households, 1995 Calibrated Economy vs Changed Inflation

Figure 7: The wealth distribution and Lorenz Curve, 1995 Calibrated Economy vs Changed Adjusted Cost

Figure 8: Financial assets holding and money holding against level of wealth of households, 1995 Calibrated Economy vs Changed Adjusted Cost....

Figure 9: The wealth distribution and Lorenz Curve, 1995 Calibrated Economy vs Changed

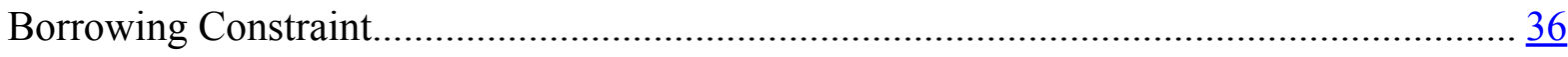

Figure 10: Financial assets holding and money holding against level of wealth of households, 1995 Calibrated Economy vs Changed Borrowing Constraint. 
Figure 11: The wealth distribution and Lorenz Curve, 1995 Calibrated Economy vs Changed

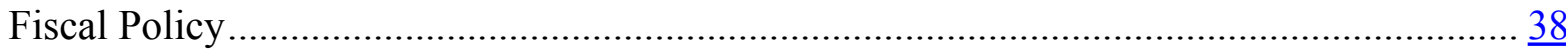

Figure 12: Financial assets holding and money holding against level of wealth of households, 1995 Calibrated Economy vs Changed Fiscal Policy ........................................................ 38

Figure A1: CHIPS 1995 Sample Wealth Distribution and Wealth Composition.................... 46

Figure A2: CHIPS 2002 Sample Wealth Distribution and Wealth Composition.................... 47 


\section{INTRODUCTION}

This paper studies the implication of inflation and financial markets development on wealth dispersion. Our study focuses on a large emerging economy, China, because the Chinese economy between mid-1990s and early-2000s has experienced significant changes in inflation and financial markets development over this period. Thus, it provides a unique natural environment for our study. We devote particular attention to the reduction in inflation and the changes in two aspects of financial development, namely, the accessibility to (Beck, Demirgüç-Kunt, and Honohan, 2009) and depth of (King and Levine, 1993) the financial markets.

A large body of literature is devoted to understanding the distributional effect of inflation and financial market development. Romer and Romer (1999) indicate a negative relationship between average inflation and the income of the poor. Using pooled household data from 38 countries, Easterly and Fischer (2001) find that poor households are more likely than rich households to mention inflation as a top national concern; this result suggests that poor households perceive inflation as more costly. Studies also find that income inequality across countries is correlated to both inflation (Albanesi, 2007) and degree of financial market development (Beck, Demirgüç-Kunt, and Levine, 2007). While it is generally agreed that market incompleteness and frictions in the economy are important factors in understanding the distributional effect of inflation and financial market development, the literature concentrates on advanced economy, such as the United States, which is a developed economy with a high degree of market completeness and a low level of financial friction. There has been no attempt to analyze this issue for developing economies in which inflation is an even greater concern and where financial markets are under-developed. This gap motivates us to examine how structural changes in both the inflation and financial market development in a less developed economy affect the decisions of households regarding asset allocation for consumption smoothing, which in turn produces further aggregate and distributional effects on the economy. ${ }^{2}$

As noted before, the macroeconomic economy environment of China between mid-1990s and early 2000s presents a unique opportunity to study issues of inflation and the effects of financial market development. First, the inflation rates in China declined from 12 percent in the early 1990s to approximately 0 percent in 2002 after a series of monetary tightening measures were implemented. Easterly and Fischer (2001) report that the percentage of people who mentioned inflation as a top national concern in China is the highest among the 38

\footnotetext{
${ }^{2}$ It is important to note here that productivity growth is also an important channel to explain the accumulation of wealth of an economy, especially at the aggregate level. However, studies, like this paper, generally assume that there is no trend growth in the aggregate productivity in the economy (i.e., focusing only on the dynamics of the "detrended" economy) to simplify the analysis.
} 
countries in the survey; thus, this result could have welfare implications for China. Second, the ongoing reforms have fostered consumer finance and lowered the transaction costs of participating in financial markets in the last two decades. For instance, it has become more common for households to hold consumer loans, access their bank accounts with ATMs, and hold equity-trading accounts in the stock market. ${ }^{3}$ Therefore, these two distinct but simultaneous developments provide a natural environment for the study.

Using unique household-level data and aggregate statistics for China over the period from 1995 to 2002, we report the following observations during this period: (1) the distributions of wealth, money, and financial assets became more equal over time; ${ }^{4}(2)$ the money-wealth ratio decreased with wealth over time; nevertheless, the portion of money in total wealth increased over time; ${ }^{5}$ and (3) the aggregate household's wealth, money holding, moneyoutput ratio, and money-wealth ratio increased.

The empirical facts above cannot be satisfactorily explained by the existing models. In particular, we need a model that can produce distributions of financial assets and money across households to explain these empirical facts simultaneously. Dynamic generalequilibrium heterogeneous-agent models with a borrowing constraint, such as the seminal model utilized by Aiyagari (1994), can potentially serve this purpose. Nevertheless, Aiyagari's model predicts that both wealth inequality and aggregate wealth decrease when the borrowing constraint is relaxed, and this prediction is inconsistent with the empirical facts above. The model by Akyol (2004) incorporates money into a heterogeneous-agent model with a borrowing constraint on financial assets. Although Akyol's model is able to predict that the money-to-wealth ratio decreases with wealth, his model is not consistent with the empirical patterns in which the aggregate wealth rises when the borrowing constraint is relaxed and inflation decreases.

To understand the empirical facts described above, we generalize the model used by Aiyagari (1994) in a manner similar to that employed by Akyol (2004) by allowing households to simultaneously hold two assets: financial assets and money. Households in our model are ex ante identical and draw an idiosyncratic labor-productivity shock from a fixed

\footnotetext{
${ }^{3}$ Shen and Yan (2009) document that bank loans to Chinese households have expanded substantially from 1.5 percent of the total outstanding bank loans in late 1999 to 8 percent in 2002. Moreover, the number of investors in the Shanghai and Shenzhen Stock Exchanges was estimated to increase from 0.37 to about 100 million over the period from 1991 to 2002 .

${ }^{4}$ Money is broadly defined as the sum of cash, checking deposits, and short-term savings deposits. In our context, financial assets are defined as the sum of all other assets. Details regarding these two definitions are discussed in the later sections.

${ }^{5}$ Our data pertaining to Chinese households are consistent with those pertaining to U.S. households as reported by Kennickell and Starr-McCluer (1997) and Wolff (2006).
} 
distribution. They choose consumption, money, and interest-bearing financial assets to maximize their life-time utilities. In contrast with Akyol (2004), who introduces the value of money through timing assumptions regarding the opening sequence of financial assets, money, and goods markets, we follow the seminal works by Chatterjee and Corbae (1992) and Alvarez, Atkeson, and Kehoe (2002) and assume that households face a fixed cost of adjusting their financial asset holdings (the portfolio adjustment cost). As a result, the portfolio adjustment cost induces some households to hold money, even though money does not yield direct utility and the return of money is dominated by that of financial assets in equilibrium.

We assume that the portfolio adjustment cost is identical across households; this assumption is necessary to ensure that the model is consistent with the empirical facts mentioned above. In particular, this assumption implies that less wealthy households face a larger fixed cost, which is measured by the marginal utility of consumption. Therefore, poor households hold more money in their portfolios relative to rich households. As a result, our model creates a wealth distribution in which the money-wealth ratio decreases with wealth. Because money is more concentrated in the hands of poor households, higher inflation then causes a greater dispersion of money holding.

We calibrate our model with the Chinese data at aggregate and household levels from two different sample periods: one period from 1995 and the other period from 2002. The portfolio adjustment cost and the borrowing constraint in the model are calibrated to replicate features of the wealth distribution in China. In particular, we calibrate these two parameters by matching the model implied fraction of households without money holding and the crosssectional average money-to-wealth ratio to be close to their counterparts as observed in the data. The portfolio adjustment cost was reduced from 23 percent to 6 percent of the average annual income from 1995 to 2002; the reduction in the portfolio adjustment cost is qualitatively consistent with the development of the Chinese financial market. Furthermore, the borrowing constraint was relaxed from completely binding to approximately 63 percent of the average annual income. The relaxation of the borrowing constraint is consistent with the increase in total wealth because it allows households to pledge a portion of their wealth as collateral for borrowing.

Our benchmark model reproduces certain important empirical patterns of the wealth distribution, money-wealth ratios, and selected macroeconomic aggregates. Counterfactual experiments isolate and quantify the effects of changes in inflation, portfolio adjustment costs, borrowing constraints, fiscal policies, and income processes on the changes in an economy. The results are as follows: (1) the reduction of inflation increases the value of money as an insurance device, which increases aggregate money holding and money-output ratios and lowers aggregate financial assets and total wealth. Reduced inflation also contributes to a more equal money distribution and higher money-wealth ratios across households; (2) portfolio adjustment cost reduction is a dominant force in decreasing the 
dispersion of the wealth and the financial asset and decreasing the aggregate money-wealth ratio because the reduction of this cost encourages households to use the financial markets to smooth shocks, and this mechanism significantly lowers precautionary saving motives; (3) the relaxation of the borrowing constraint enables households to use the credit market for consumption smoothing and causes the wealth distributions and the financial asset distribution to be more equal than before the relaxation; and (4) the reduction of the adjustment cost yields the largest welfare gain.

The first contribution of the paper is theoretic. First, we show that a heterogeneous-agent model with multiple assets, a portfolio adjustment cost and a borrowing constraint is capable of generating the observation that aggregate wealth increases and the wealth distribution becomes more equal across households when the borrowing constraint is relaxed; this result differs from that is predicted by the Aiyagari (1994) model. The relaxation of the borrowing constraint reduces the dispersion of wealth by extending the limits for household borrowing and lending. To economize the cost of using credit markets, more households hold more financial assets to earn interest income to pay for the portfolio adjustment cost. In the long run, therefore, the model implies that more households will be clustered around a higher level of financial asset holdings, which results in higher aggregate wealth with a lower dispersion of wealth. In contrast, when the portfolio adjustment cost is zero, the households in our model do not hold money but hold only financial assets. In this case, our model shows that both the dispersion of financial asset holdings and aggregate wealth decline after the borrowing constraint is relaxed, as predicted by Aiyagari (1994).

Our paper also contributes to the literature by examining the distributional effect of inflation using a dynamic general-equilibrium model with heterogeneous agents. Erosa and Ventura (2002) and Albanesi (2007) assume that in the presence of economies of scale in costly credit purchases, high-income households face lower transaction costs when purchasing consumption goods. The former paper argues that inflation acts as a regressive tax and widens the wealth distribution, whereas the latter paper shows that high inflation and low levels of labor tax is an outcome of a "political equilibrium" of fiscal policy under high income inequality. Our paper departs from these two papers by introducing the demand for money through a portfolio choice problem, in which households decide the allocation between money and financial assets endogenously rather than assuming that households use a credit-transaction technology.

As mentioned previously, studies that are closely related to our work are, among others, Chatterjee and Corbae (1992), Alvarez et al. (2002), and Heer and Süssmuth (2007). These papers also rely on a portfolio adjustment cost to generate non-trivial money demand. Our work is different from these papers, in which, we use both the depth of (as measured by the size of the borrowing constraint) and accessibility to (as measured by the size of the portfolio adjustment cost) the financial market to understand the determinants of a wealth distribution. By varying the borrowing constraint, we are able to quantify the importance of the depth of 
the financial market in affecting the wealth distribution. Moreover, our analysis of the effects of financial development on the wealth distribution, wealth composition, and macroeconomic aggregates, are more comprehensive than those of the previous studies.

The second contribution of our paper is to contribute to the discussion of the distributional impact of inflation and financial market developments in China. With regard to the process of China transitioning to a market-based system and being integrated into the global economy, Goodfriend and Prasad (2007) suggest that an environment with a low inflation rate can stabilize the economy against external shocks and promote long-term economic growth. However, Amato and Gerlach (2002) argue that the process of implementing a policy of low inflation rates in developing countries is not straightforward, even though this policy is widely adopted in industrialized countries. In particular, the effect of uninsurable idiosyncratic risk is stronger in developing economies than in developed economies because the degree of market completeness in developing countries is lower than in developed countries. Our results suggest that adopting a low-inflation policy is particularly beneficial to households in economies with underdeveloped financial markets because it can lower the cost of holding money, which is an important insurance device for households, especially the poor ones, to smooth shocks. In addition, our results also suggest that structural reform aim at fostering the development of financial market could help reduce inequality.

We introduce the model in the next section. Section 3 discusses the data and calibration. Section 4 reports our main results. Section 5 concludes.

\section{THe Model ECONOMY}

We consider a production economy populated by a continuum of infinitely lived households of measure one. We focus the analysis on steady states. The output price in the current period is normalized to 1 . We denote $x$ ' as the value of a variable, $x$, in the next period.

\section{A. Technology}

Aggregate output, $Y$ is produced according to an aggregate Cobb-Douglas production function that takes aggregate capital, $K$, and aggregate labor, $L$, as inputs:

$$
Y=K^{\alpha} L^{1-\alpha},
$$

where $\alpha \in(0,1)$ is the income share of capital. The final good can be consumed by households, consumed by the government, or invested in capital. Thus, the feasibility constraint is as follows:

$$
C+\overline{\tau_{a}}+I_{k}+G=F(K, L),
$$

where $C$ is nondurable consumption, $\overline{\tau_{a}}$ is the aggregate portfolio adjustment cost incurred by households, $I_{k}$, is investment in capital, and $G$ is government consumption. The government consumption is exogenous. 


\section{B. Preferences and Endowments}

Households derive utility only from the consumption of a nondurable good $(c)$. The expected lifetime utility function of a household at time $t$ is given by the following:

$$
U_{t}=\mathrm{E}_{t}\left[\sum_{s=0}^{\infty} \beta^{s} \frac{c_{t+s}^{1-\sigma}-1}{1-\sigma}\right],
$$

where $\beta$ is the subjective discount rate and $\sigma$ is the coefficient of constant relative risk aversion.

Households take the wage as given and supply one unit of labor service inelastically. In each period, they receive a shock to their efficiency units of labor, $\varepsilon \in\left\{e_{1}, e_{2}, \cdots, e_{L}\right\}$. The shock is household-specific and is identical and independently distributed (i.i.d.) across households. The shock process follows a first-order Markov process with the transition probability of transitioning from $e_{h}$ realized in the current period to $e_{k}$ in the next period (denoted by superscript ' $), \operatorname{Pr}\left[\varepsilon^{\prime}=e_{k} \mid \varepsilon=e_{h}\right]$ for all $h, k$.

\section{Market Arrangements}

There are no state-contingent claims markets for households to fully insure their idiosyncratic productivity shock. Households, however, can hold illiquid interest-bearing financial assets, $a \in[\underline{a}, \infty), \underline{a} \in \mathrm{R}$, and money, $m \in[0, \infty)$. The borrowing constraint $\underline{a}$ is exogenous and is identical across households. Financial assets pay a net real interest rate, $r$, and there is no difference between the borrowing and lending rates.

Following Díaz and Luengo-Prado (2010), we introduce the liquidity of financial assets by assuming that households must pay a non-convex adjustment cost $\rho_{a}$ when they change their financial asset holdings. Specifically, the adjustment-cost function is given by $\tau_{a}\left(a^{\prime}, a\right)=\rho_{a} \mathrm{I}\left[a^{\prime} \neq(1+r) a\right]$, and $\mathrm{I}[x]$ is an indicator function that takes the value of 1 if $x$ is true and 0 otherwise. These costs can be interpreted as the transaction costs for trading activities (such as commission fees) and the opportunity costs of acquiring basic information regarding the financial markets. ${ }^{6}$

The portfolio adjustment cost induces infrequent changes in financial asset holdings and nontrivial money demand from households for insuring against income shocks. Intuitively, the portfolio adjustment cost lowers the incentives of households to use their financial assets to smooth income shocks. Because consumption smoothing by money does not entail a portfolio adjustment cost, households hold money for precautionary savings when the benefit

\footnotetext{
${ }^{6}$ We assume that households do not need to pay the adjustment cost if a change of balance arises from the natural interest accumulation.
} 
of having a smoother consumption profile outweighs the cost of holding money. Thus, the portfolio adjustment cost generates money demand endogenously through the provision of liquidity services. Moreover, money demand decreases when (1) the portfolio adjustment cost decreases because households will increase the use of the financial market for precautionary saving and when (2) inflation increases because inflation erodes the insurance value of money. Notably, our model contrasts with the models that do not incorporate this friction, in which households do not hold money, or with the models that rely on behavioral assumptions to introduce money demand (for example, Cash-In-Advance, Money-in-theUtility or transaction technology).

\section{The Dynamic Programming Problem of Households}

The description of the problem of households can be formulated as a dynamic programming problem. A household chooses $\left\{c, a^{\prime}, m^{\prime}\right\}$ to solve the following dynamic programming problem:

$$
\begin{aligned}
& v(a, m, \varepsilon)=\quad \max _{c, a^{\prime}, m^{\prime}}\left(u(c)+\beta_{\varepsilon}\left[v\left(a^{\prime}, m^{\prime} ; \varepsilon^{\prime}\right)\right]\right) \\
& \text { s.t. } \quad m^{\prime}+a^{\prime}+c+\tau_{a}\left(a^{\prime}, a\right)=u(1-v) \varepsilon+(1+r) a+\frac{m}{1+\pi} \quad, \\
& a^{\prime} \geq \underline{a}
\end{aligned}
$$

where $m^{\prime} \equiv \frac{M^{\prime}}{P}=M^{\prime}, \pi=\frac{P-P_{-1}}{P_{-1}}=\frac{1-P_{-1}}{P_{-1}}$ is the net inflation rate from the previous period, $P_{-1}$, to the current period, $w$ is the wage per efficiency labor unit, and households pay a labor income tax at the rate of $v$ to the government.

\section{E. The Firm's Problem}

There is a representative firm that takes the price of output, the price of capital, and the wage as given and solves the following static problem:

$$
\max _{K, L} K^{\alpha} L^{1-\alpha}-p_{k} K-w L,
$$

where $p_{k}$ is the price of capital. At equilibrium,

$$
\begin{aligned}
& p_{k}=\alpha\left(\frac{K}{L}\right)^{\alpha-1}, \\
& w=(1-\alpha)\left(\frac{K}{L}\right)^{\alpha} .
\end{aligned}
$$

\section{F. Government}

The government faces an exogenous stream of government spending, $G$. Government spending is financed by levying the labor income tax on the households. The government borrows to compensate for the current budget deficit or deposits any budget surplus in a financial institution. We denote the net interest rate of a government bond by $r_{g}$ (assuming 
that the government faces the same rate when saving), and the flow budget constraint of the government (in real terms) is as follows:

$$
G+\left(1+r_{g}\right) B+\frac{\bar{m}_{s}}{1+\pi}=\bar{v}+\bar{m}_{s}^{\prime}+B^{\prime},
$$

where $B$ denotes the amount of government bonds outstanding (which is negative when the government saves), $\bar{v}=\mathrm{wLv}$ is the aggregate amount of tax collected from households, and $\bar{m}_{s}$ is the aggregate money supply outstanding in the economy. In the long term, the inflation rate $\pi$ equals the growth rate of the money supply chosen by the government. As a result, the flow budget constraint of the government at the stationary equilibrium is as follows:

$$
G+r_{g} B=\bar{v}+\frac{\pi \bar{m}_{s}}{1+\pi}
$$

\section{G. The Financial Institution's Problem}

There is a risk-neutral financial institution that pools the financial assets of households, $A$, and lends $B$ to the government (or borrows from the government if $B<0$ ). The financial institution transforms the net balance of financial assets into physical capital, $K$ (without cost), and rents to the firm for production. The rate of depreciation is denoted by $\delta_{k}$. The financial institution solves the following problem:

$$
\begin{gathered}
\Psi(A, B)=\max _{A^{\prime}, B^{\prime}, K}\left(A-B^{\prime}-(1+r) A+\left(p_{k}-\delta_{k}\right) K+\left(1+r_{g}\right) B+\frac{\Psi\left(A^{\prime}, B^{\prime}\right)}{1+r}\right) \\
\text { s.t. } \quad K=A-B
\end{gathered}
$$

The financial institution earns zero profit at the stationary long run equilibrium. The no arbitrage condition $r=r_{g}=p_{k}-\delta_{k}$ must be satisfied at equilibrium to ensure that the problem is well defined. ${ }^{7}$

\section{H. Stationary Equilibrium}

The stationary equilibrium of the model economy is defined as follows. We denote the vector of the state variable of the household as $x=\{\varepsilon, a, m\}$ and $X=\{E \times[\underline{a}, \infty] \times[0, \infty]\}$. A stationary equilibrium of the economy is given by a vector of a real interest rate, a wage and an inflation rate $(r, w, \pi)$; the value function $v(x)$ and a set of policy functions for choosing the asset $g_{a}(x)$, money holding $g_{m}(x)$ and consumption $g_{c}(x)$ that solves the household problem; and the distribution of households defined over the state variable, $\mu(x)$, that jointly satisfy the following conditions:

\footnotetext{
${ }^{7}$ See Diaz and Luengo-Prado (2010) for more information about the treatment of the financial institution's problem.
} 
1. Given $\mu, r$ and $\pi$, the functions $\left\{v(x), g_{a}(x), g_{m}(x), g_{c}(x)\right\}$ solve the households' dynamic programming (Equation 4).

2. Total labor services are obtained by aggregating efficiency labor units, $\varepsilon$, across households, $L=\int_{x} \varepsilon d \mu$.

3. The private-sector financial asset holding position: $A=\int a d \mu=\int g_{a}(x) d \mu$.

4. Total money holding, $\bar{m}_{s}=\int m d \mu=\int g_{m}(x) d \mu$.

5. Total private consumption, $C=\int g_{c}(x) d \mu$.

6. Total investment in physical capital, $I_{k}=\delta_{k} K$.

7. Total financial asset adjustment cost, $\overline{\tau_{a}}=\int \tau_{a}\left(g_{a}(x), a\right) d \mu$.

8. The government flow budget constraint satisfies $G+r B=\bar{v}+\frac{\pi \bar{m}}{1+\pi}$.

9. The aggregate amount of tax, $\bar{v}=\int v d \mu=v$.

10. Total supply of capital, $K=A-B$.

11. The price of capital is $p_{k}=\alpha\left(\frac{K}{L}\right)^{\alpha-1}$, and the wage (per unit of efficiency labor $)$ is $w=(1-\alpha)\left(\frac{K}{L}\right)^{\alpha}$.

12. No arbitrage conditions, $r=r_{g}=p_{k}-\delta_{k}$.

13. The feasibility constraint is satisfied: $G+C+\overline{\tau_{a}}+I_{k}=Y$.

14. The distribution of households, $\mu$, is stationary (i.e., given the prices implied by the distribution, the decision rules of households replicate the same measure $\mu$ in the following period).

The stationary equilibrium of the model is solved numerically, and the solution procedure is presented in the Appendix I.

\section{Calibration}

We discuss the calibration strategy for the model in this section. We first describe the microlevel data sets pertaining to income and wealth composition that we used for calibration. The data sets separately cover the information obtained in 1995 and in 2002. We then discuss the calibration strategy with the use of statistics at the aggregate level (covering the period from 1990 to 2002) and the micro-level data. We refer to the model calibrated to the sample period from 1990 to 1995 as the 1995-economy and the model calibrated to the sample period from 1998 to 2002 as the 2002-economy. 


\section{A. Micro-level Data on Income and Wealth}

The sources of the micro-level data are the Chinese Household Income Projects (CHIPS). One project was conducted in 1995, and the other project was conducted in $2002{ }^{8}$ The data were collected through surveys in eleven provinces by the Institute of Economics, Chinese Academy of Social Sciences, in 1995 and 2002. The two surveys are consistent with one another regarding income, wealth, and demographic information regarding household members. These two data sets have been employed by previous researchers to study changes in income inequality (Démurger, Fournier, and Li, 2006) and wealth inequality (Meng, 2007) in China.

Income data are available for urban individuals in the CHIPS data for 1995 and 2002. ${ }^{9}$ Although the two surveys are repeated in a cross-sectional manner and do not track the same households over time across the two survey years, individuals in each survey were asked to report their total incomes for both survey years (1995 and 2002) and for previous years. In the CHIPS data for 1995, individual incomes are available for each year from 1990 to 1995 , and the CHIPS data for 2002 report individual incomes for the years from 1998 to 2002 . We deflate the total income to 1990 prices using the deflator developed by Brandt and Holz (2006). ${ }^{10}$

To characterize income dynamics, we use only working age individuals (aged between 15 and 64 at the beginning of the sample) with complete income information from 1990 to 1995 for CHIPS 1995 and from 1998 to 2002 for CHIPS 2002. To reduce the effect of measurement errors, we use the following rules to filter our samples. In each survey, we first remove the observations with substantial misreporting (negative reported labor income and missing observations in any reporting years in the survey). We then compute the (time series) average income of each individual and omitted individuals with incomes that are ten times larger or smaller than their average in any year. In the final step, we remove outlying observations by eliminating individuals with (time series) average incomes that are smaller than the 1st percentile or larger than the 99th percentile of the (time series average) income distribution of households in each survey. As a result, the numbers of households included were 12,648 and 12,558 for the 1995 and 2002 surveys, respectively.

\footnotetext{
${ }^{8}$ A more detailed description of the datasets is available in Appendix II.

${ }^{9}$ Total income is the before-tax income, which is the sum of labor income, property income, transfer income, and income from household production. Labor income is by far the largest component of the total income.

${ }^{10}$ The deflator developed in Brandt and Hotz (2006) is a spatial price deflator for urban areas, which is an urban area specific price deflator.
} 
With regard to the data on household wealth, we divide the total household wealth by the household size to obtain the wealth per capita. ${ }^{11}$ Wealth is deflated by the same price deflator that is used for income. We apply the same filtering rules to filter outlying observations of wealth. In particular, we remove the outlying observations by omitting observations of total wealth below the 1 st percentile and above the 99th percentile in each survey.

We categorize the total wealth into two groups: money and financial assets. The money consists of liquid assets, such as demand deposits and saving deposits (which usually do not entail adjustment costs). The financial assets primarily consist of illiquid assets, including longer-term time deposits, stocks, bonds, and housing wealth. ${ }^{12}$ Table 1 presents some descriptive statistics of the income and wealth data discussed above.

\footnotetext{
${ }^{11}$ Income is reported at the individual level, and wealth is reported at the household level. Therefore, there is no one-to-one correspondence between income and wealth at the individual level.

${ }^{12}$ Although the analysis would be more realistic and richer if return on illiquid assets could be separately determined for, say, longer-term time deposits, stocks and bonds, we are unable to match actual returns with household data. This may affect how households adjust their portfolio.
} 
Table 1: Descriptive Statistics on Reported Incomes and Wealth

\begin{tabular}{|l|l|l|l|l|l|l|l|l|}
\hline & \multicolumn{4}{|c|}{ CHIPS 1995 } & \multicolumn{4}{c|}{ CHIPS 2002 } \\
\hline & Mean & SD & Gini & CV & Mean & SD & Gini & CV \\
\hline Income & 3601 & 1835 & 0.27 & 0.51 & 4787 & 2913 & 0.31 & 0.61 \\
\hline Money & 656 & 1299 & 0.75 & 1.98 & 2076 & 4073 & 0.69 & 1.96 \\
\hline $\begin{array}{l}\text { Financial } \\
\text { Assets }\end{array}$ & 13553 & 17337 & 0.59 & 1.28 & 49558 & 42762 & 0.44 & 0.86 \\
\hline Wealth & 14209 & 17691 & 0.58 & 1.25 & 51634 & 44162 & 0.43 & 0.86 \\
\hline
\end{tabular}

Note: The values of each entry are in real-term, 1990 prices (unit in RMB). The row Income refers to the 5-year time-series average of the reported income of individuals in the sample in each survey. Column Mean, SD, Gini, and CV refers to the crosssectional mean, the cross-sectional standard deviation, the Gini, and the Coefficient of Variations of individual time-series averages of the respective variables. Income at individual level: the numbers of observation are 12648 and 12558 for the CHIPS 1995 and CHIPS 2002, respectively. The row Money and Financial Assets refer to the stock of liquid assets and all other assets of individuals as of the survey year, respectively. The row Wealth is the sum of Money and Financial Assets. The numbers of observation for wealth data are 6862 and 6699 for the CHIPS 1995 and CHIPS 2002, respectively.

The table shows that the means and standard deviations of income, wealth, financial assets, and money increased from 1995 to 2002, as expected, as a result of the economic growth between the two sample years. ${ }^{13}$ The standard deviations increased across the two sample periods because of the level effect. Thus, we also examine measures, such as the Gini coefficient (Gini) and the coefficient of variation $(\mathrm{CV})$, which are less sensitive to the level of the variable of interest.

The Gini coefficients of total wealth were 0.58 and 0.43 for 1995 and 2002, respectively. However, the Gini coefficients of income were 0.27 and 0.31 for the years 1995 and 2002, respectively. This result suggests that the change in income dispersion cannot explain the decrease in wealth inequality. With regard to the composition of the household portfolio, the Gini coefficients for money and financial assets were 0.75 and 0.59 in 1995 and decreased to 0.69 and 0.44 in 2002, respectively. The CVs provide a similar picture as that provided by the Gini coefficients.

\footnotetext{
${ }^{13}$ The increase in housing ownership is also a key factor to the increase in household wealth (Meng, 2007). Recall that housing wealth is included in our measure of financial assets. There was a dramatic increase in home ownership during the period of housing reform from 1995 to 1999.
} 


\section{B. Preference and Production}

The parameters governing the shape of the preference and production technology are calibrated as follows. We set $\beta=0.96$, which implies a real interest rate of approximately 4 percent annually, in the absence of borrowing constraints and portfolio adjustment costs. We set the coefficient of relative risk aversion as $\sigma=1.5$, which lies within the reasonable range used in the literature (for example, Akyol, 2004; Díaz and Luengo-Prado, 2010). For the production function, we use the information provided by Bai, Hsieh, and Qian (2006, Table 1) and calibrate $\alpha=0.48$ and $\delta_{k}=0.11$, which are the average income share of capital and the depreciation rate from 1978 to 2005.

\section{Monetary and Fiscal Policy}

We employ the aggregate statistics over the period from 1990 to 2002 obtained from the China Statistical Yearbook to calibrate the parameters for monetary and fiscal policies. We set the inflation rate in the 1995 economy to 12.2 percent and the rate in the 2002 economy to 0.28 percent, which were the six-year average annual inflation rates from 1990 to 1995 and from 1997 to 2002, respectively.

The ratios of government expenditures to GDP (i.e., the parameter $\frac{G}{Y}$ ) in the 1995 economy and the 2002 economy are calibrated in the same way as the inflation rate and were set to 14 percent and 17 percent, respectively. Because we do not have individual income tax data, we assume that the tax revenue of the government is borne by all households. According to the data, we set the ratios of tax revenue to GDP (i.e., the parameter $\frac{\bar{v}}{Y}$ ) in the 1995 economy to 12.5 percent and in the 2002 economy to 14 percent. The labor income tax rate was then endogenously calibrated as follows:

$$
v=\frac{\bar{v}}{w L}=\frac{\bar{v}}{Y} \frac{Y}{w L}
$$

\section{Income Process}

To calibrate the individual productivity shocks, we utilize the micro-level income observations described above to estimate a dynamic income process for households as usually done in the literature. Specifically, for each sample period, we follow Heaton and Lucas (1996) and estimate the following dynamic income process:

$$
\log y_{i t}=\log \bar{y}+\rho \log y_{i t-1}+\sigma_{\varepsilon} \varepsilon_{i t}
$$

where $y_{i t}=\frac{\text { income }_{i t}}{\text { sum }_{i} \text { income }_{i t}}$ and $\varepsilon$ is the i.i.d. income shocks. We estimate this dynamic panel data model using the generalized method of moments (GMM) estimator proposed by 
Blundell and Bond (1998), which is an enhanced estimator compared with the firstdifferenced GMM estimator developed by Arellano and Bond (1991).

Arellano and Bond (1991) transform the model by first-differencing to remove unobserved time-invariant individual-specific components and then instrument the lagged dependent variable in the first-differenced equation using the level series of at least two lagged periods under the assumption that the time-varying disturbances in the original-level equations are not serially correlated. The moment conditions proposed by Arellano and Bond (1991) are as follows:

$$
\mathrm{E}\left[\Delta \varepsilon_{i t} \log y_{i t-s}\right]=0, \forall i, s \geq 2 \text { and } t \geq 3 .
$$

However, Blundell and Bond $(1998,2000)$ argue that when the time series are persistent and the number of time series observations is small, the first-differenced GMM estimator has large finite sample biases and is imprecise because the instrumental variables are weak. Thus, they propose a GMM estimator that exploits an assumption regarding the initial conditions to obtain moment conditions that remain informative even for persistent series, and they show that the estimator performs well in simulations. They propose supplementing the previous moment conditions by the following moments:

$$
\mathrm{E}\left[\varepsilon_{i t} \log y_{i t-1}\right]=0 \text {, for all } i \text { and } t \geq 3 \text {. }
$$

The estimation results of the income process are reported in Table 2 below. The estimated income persistence parameter, $\rho$ is 0.76 in 2002, which is higher than the parameter (0.72) in 1995. Moreover, the standard deviation of the income shocks in 1995 is 0.25 , which is also close to that in $2002(0.26)$. The estimated mean of the income process also increased from 0.45 in 1995 to -0.33 in 2002. This change indicates that income dynamics in China changed over the two sample periods. ${ }^{14}$

\footnotetext{
${ }^{14}$ Our estimates of the income persistence for both sample periods are higher than the OLS estimates reported in Khor and Pencavel (2010). We employed the fixed effect to control for unobserved heterogeneity across individuals, which controls for the potential negative correlation between lagged income and current income shocks due to reversals in the income process.
} 
Table 2: Estimation of Income Process, CHIPS 1995 and CHIPS 2002

\begin{tabular}{|c|c|c|}
\hline & CHIPS1995 & CHIPS2002 \\
\hline $\log \bar{y}$ & -0.45 & -0.33 \\
\hline (S.E.) & $(0.01)$ & $(0.01)$ \\
\hline$\rho$ & 0.72 & 0.76 \\
\hline (S.E.) & $(0.01)$ & $(0.01)$ \\
\hline$\sigma_{\varepsilon}$ & 0.25 & 0.26 \\
\hline Observation & 12,648 & 12,558 \\
\hline \multicolumn{3}{|c|}{$\begin{array}{l}\text { Note: The equation for the income process } \\
\text { is } \log y_{i t}=\log \bar{y}+\rho \log y_{i t-1}+\sigma_{e} \varepsilon_{i t} \\
\text { The column presents the estimation of the } \\
\text { income process based on the reported } \\
\text { income in CHIPS } 1995 \text { and CHIP2002. Row } \\
\text { S.E. presents the standard errors for the } \\
\text { estimated parameter. The model is } \\
\text { estimated by Blundell and Bond (1998, } \\
\text { 2000) GMM estimator. }\end{array}$} \\
\hline
\end{tabular}

As commonly done in the literature, we first discretized the estimated income process by a four-point Markov chain using the procedure described by Rouwenhorst (1995). The resulting discretized income process contains a vector of income shock (with 4 elements here) and a transition probability matrix used to describe the conditional probability of moving one level of income shock to another between two consecutive periods (as a 4-by-4 matrix here; each row corresponds to the conditional probability distribution of moving to all four states in the next period, conditional on being in a particular state in the current period). We then use this vector of income and the transition matrix to solve household's dynamic programming problem. Kopecky and Suen (2010) show that the approximation of a stationary autoregressive shock process using the Rouwenhorst method yields more accurate solutions for typical models than other methods, such as those employed by Tauchen (1986) and Tauchen and Hussey (1991), when the shock process is very persistent. The resulting Markov chains of the income process for CHIPS1995 and CHIPS2002 are reported in Table 3 below. 
Table 3: The transition matrix of the Discretized Income Process

\begin{tabular}{|c|c|c|c|c|}
\hline \multicolumn{5}{|c|}{ CHIPS 1995} \\
\hline & \multirow{2}{*}{\multicolumn{4}{|c|}{$\begin{array}{l}\text { Transition Matrix } \\
\text { Future Income, } \varepsilon^{\prime}\end{array}$}} \\
\hline & & & & \\
\hline \multirow{4}{*}{ Current Income, $\varepsilon$} & 0.64 & 0.31 & 0.05 & 0.00 \\
\hline & 0.10 & 0.67 & 0.21 & 0.02 \\
\hline & 0.02 & 0.21 & 0.67 & 0.10 \\
\hline & 0.00 & 0.05 & 0.31 & 0.64 \\
\hline $\begin{array}{c}\text { Stationary } \\
\text { Distribution }\end{array}$ & 0.13 & 0.37 & 0.37 & 0.13 \\
\hline Discretized Income & 0.54 & 0.81 & 1.23 & 1.85 \\
\hline \multicolumn{5}{|c|}{ CHIPS 2002} \\
\hline & \multicolumn{4}{|c|}{ Transition Matrix } \\
\hline & \multicolumn{4}{|c|}{ Future Income, $\varepsilon^{\prime}$} \\
\hline \multirow{4}{*}{ Current Income, $\varepsilon$} & 0.68 & 0.28 & 0.04 & 0.00 \\
\hline & 0.09 & 0.71 & 0.19 & 0.01 \\
\hline & 0.01 & 0.19 & 0.71 & 0.09 \\
\hline & 0.00 & & & \\
\hline $\begin{array}{l}\text { Stationary } \\
\text { Distribution }\end{array}$ & 0.13 & 0.37 & 0.37 & 0.13 \\
\hline Discretized Income & 0.50 & 0.79 & 1.26 & 2.02 \\
\hline \multicolumn{5}{|c|}{$\begin{array}{l}\text { Note: Each panel presents the transition matrix } \\
\text { results from discretizing the estimated income } \\
\text { process based on reported income in CHIPS1995 } \\
\text { and CHIPS 2002. Rows Current Income in the } \\
\text { transition matrix are the conditional probability of } \\
\text { transiting from one state to all other states, thus, the } \\
\text { sum is one. Row Stationary Distribution presents the } \\
\text { stationary probability distribution based on the } \\
\text { transition probability matrix. Row Discretized } \\
\text { Income is the level of productivity in each state } \\
\text { resulting from the discretization of the income } \\
\text { process. }\end{array}$} \\
\hline
\end{tabular}

\section{E. Financial Market Frictions}

There are two critical features in our model that generate the effect of inflation on wealth distribution: the borrowing constraint and the fixed cost for portfolio adjustment. Because there are no existing estimates of these two parameters for China, we calibrate them, conditional on other parameters, by matching the model-generated fraction of households 
without money holding (MO) and cross-sectional average money-to-wealth ratio $(C S)$ to those observed in the data. ${ }^{15}$

This calibration strategy follows an implication from the study conducted by Aiyagari (1994), in which a wealth distribution can be obtained from a model with a borrowing constraint and idiosyncratic shocks to individuals (such as income shocks). When the borrowing constraint is relaxed, the distributions of wealth, financial assets, and money holdings change. Thus, the average money-to-wealth ratio is one statistic that can inform us about the shape of these three distributions. On the other hand, because money is non-interest bearing, a lower portfolio adjustment cost reduces the money holdings of all households, and therefore will also affect the shape of the wealth distribution, the financial asset holding distribution, and the money holding distribution. Therefore, the fraction of households that do not hold money, which reflects the size of portfolio adjustment cost, also provides information about the wealth distributions. We calibrate these two parameters by minimizing the equally weighted quadratic loss function for 1995 and 2002 independently:

$$
L\left(\underline{a}, \rho_{a}\right)=(M 0(\text { model })-M 0(\text { data }))^{2}+(C S(\text { model })-C S(\text { data }))^{2} .
$$

The calibrated portfolio adjustment costs for 1995 and 2002 are 0.35 and 0.1, respectively, and the calibrated borrowing constraints for 1995 and 2002 are 0 and 1, respectively. The results indicate that the portfolio adjustment costs decrease and the borrowing constraints are relaxed across the two survey years.

According to Tables A2 and A3 (in Appendix II), the wealth-income ratio increased from 3.9 to 10.8 from 1995 to 2002 . Our results echo the nation-wide housing reform in China, which began to sell public housing units to existing tenants in urban areas in 1994. Households living in state-owned housing were given the opportunity to purchase full or partial property rights to their current apartments at prices that were significantly below their market values. As a result, the relaxation of the borrowing constraint is consistent with the notion that households are able to use housing wealth as collateral for personal loans from banks. Consistently, Shen and Yan (2009) documented that bank loans to the Chinese household sector have expanded substantially from approximately 1.5 percent of the total outstanding bank loans in 1999 to 8 percent in 2002.

Reduction in the fixed cost for portfolio adjustment encourages households to participate in financial markets. For instance, since the opening of the stock exchange in 1991, the number of investors in the Shanghai and Shenzhen Stock Exchanges increased from 0.37 million to

\footnotetext{
${ }^{15} \mathrm{We}$ also considered other variables used for calibration here. We find that these two variables yield the best results.
} 
130 million over the period from 1991 to $2007 .{ }^{16}$ Moreover, the transaction cost of using banking services decreased as ATM and Internet banking became more popular in China.

\section{RESUlts}

This section presents the main results of the paper. Table 4 summarizes the calibration of the parameter values of the model. Column 1995 Calibrated Economy and 2002 Calibrated Economy present the calibrated parameter values of the model, with CHIPS 1995 and CHIPS 2002, respectively.

\footnotetext{
${ }^{16}$ Figures are extracted from various issues of the Shanghai and Shenzhen Stock Exchanges yearbooks.
} 
Table 4: Calibration of parameter values of the Chinese Economy in 1995 and 2002

\begin{tabular}{|c|c|c|c|}
\hline Description & Parameter & $\begin{array}{l}1995 \\
\text { Calibrated } \\
\text { Economy }\end{array}$ & $\begin{array}{l}2002 \\
\text { Calibrated } \\
\text { Economy }\end{array}$ \\
\hline \multicolumn{4}{|c|}{ Preference: $U=\mathrm{E}_{0}\left[\sum_{t=0}^{\infty} \beta \frac{c_{t}^{1-\sigma}-1}{1-\sigma}\right]$} \\
\hline Subjective Discount Rate & $\beta$ & \multicolumn{2}{|c|}{0.96} \\
\hline $\begin{array}{c}\text { Coefficient of Relative Risk } \\
\text { Aversion }\end{array}$ & $\sigma$ & \multicolumn{2}{|c|}{1.5} \\
\hline \multicolumn{4}{|c|}{$\begin{array}{l}\text { Production Function: } F(K, L)=K^{\alpha} L^{1-\alpha} \\
\end{array}$} \\
\hline Capital Income Share & $\alpha$ & \multicolumn{2}{|c|}{0.48} \\
\hline Capital Depreciation Rate & $\delta_{k}$ & \multicolumn{2}{|c|}{0.11} \\
\hline \multicolumn{4}{|c|}{ Government Policies } \\
\hline Inflation & $\pi$ & $12.2 \%$ & $0.3 \%$ \\
\hline Government Expenditure & $G$ & $14 \%$ & $17 \%$ \\
\hline Output & $\bar{Y}$ & & \\
\hline $\operatorname{Tax}$ & $v$ & $24.7 \%$ & $27.3 \%$ \\
\hline$\overline{\text { Output }}$ & $\bar{Y}$ & & \\
\hline \multicolumn{4}{|c|}{ Income Process } \\
\hline Persistence & $\rho$ & 0.72 & 0.76 \\
\hline Volatility & $\sigma_{\varepsilon}$ & 0.25 & 0.26 \\
\hline \multicolumn{4}{|c|}{ Financial Market Development } \\
\hline Borrowing Constraint & $\underline{a}$ & 0 & 1 \\
\hline Adjustment Cost & $\rho_{a}$ & 0.35 & 0.1 \\
\hline
\end{tabular}

We first discuss several characteristics of the two calibrated economies in the first subsection; one economy is based on information from CHIPS 1995 and the other economy is based on CHIPS 2002 data. We then conduct a series of counterfactual experiments based on the economy calibrated with CHIPS 2002 data to understand the roles of inflation, portfolio adjustment costs, borrowing constraints, fiscal policies, and income processes in determining changes in nominal aggregates, wealth inequality, and money-wealth ratios. The effects of changes in income processes and fiscal policies are discussed at the end of this section.

\section{A. Benchmark Calibration}

Table 5 below reports several statistics pertaining to the two calibrated economies. The calibrated models perform reasonably well in matching the dispersion of the empirical 
distribution of wealth and its components. The Gini coefficients of the financial assets and money of the calibrated 1995 economy are 0.57 and 0.73 , respectively, which are relatively consistent with their empirical counterparts (financial assets: 0.59 and money: 0.75 in 1995). The Gini coefficients of financial assets and money in the 2002 economy are 0.44 and 0.59 , respectively, which slightly underestimate the Gini coefficient of the empirical money holding distribution (financial asset: 0.44 and money: 0.69 in 2002). The model implies that wealth distributions also have magnitudes of CVs that are similar to those of their empirical counterparts for both sample periods, except for the distribution of money holding, for which our model produces $\mathrm{CV}$ values in both sample periods that are lower than those in the data. 
Table 5: Key macroeconomic statistic based on model under benchmark calibration and data

\begin{tabular}{|c|c|c|c|c|}
\hline & \multicolumn{2}{|c|}{1995} & \multicolumn{2}{c|}{2002} \\
\hline & $\begin{array}{c}\text { Calibrated } \\
\text { Economy }\end{array}$ & Data & $\begin{array}{c}\text { Calibrated } \\
\text { Economy }\end{array}$ & Data \\
\hline Consumption & $49 \%$ & $41 \%$ & $46 \%$ & $39 \%$ \\
\hline Investment & $35 \%$ & $58 \%$ & $36 \%$ & $58 \%$ \\
\hline Capital & $317 \%$ & $231 \%$ & $328 \%$ & $286 \%$ \\
\hline Money & $7 \%$ & $14 \%$ & $12 \%$ & $17 \%$ \\
\hline \multicolumn{5}{|c|}{ Gini Coefficients } \\
\hline Money & $2.4 \%$ & $3.8 \%$ & $4.4 \%$ & $5.1 \%$ \\
\hline Wealth & \multicolumn{5}{|c|}{0.58} & 0.43 & 0.43 \\
\hline \multicolumn{5}{|c|}{ Coefficient of Variation } \\
\hline Wealth & 0.57 & 0.59 & 0.44 & 0.44 \\
\hline $\begin{array}{c}\text { Financial } \\
\text { Assets }\end{array}$ & 0.57 & 1.25 & 0.84 & 0.86 \\
\hline Money & 0.73 & 0.75 & 0.59 & 0.69 \\
\hline \multicolumn{5}{|c|}{1.28} \\
\hline $\begin{array}{c}\text { Wealth } \\
\text { Assets }\end{array}$ & 1.10 & 0.87 & 0.86 \\
\hline Money & 1.53 & 1.98 & 1.11 & 1.96 \\
\hline $\begin{array}{l}\text { Note: Staff calculated. The table reports selected aggregate variables (as of } \\
\text { percentage of output) based on the calibrated models and their data } \\
\text { counterpart. }\end{array}$
\end{tabular}

The model is also fairly consistent with the Chinese economy at the macro-level along a number of dimensions that were not calibrated, particularly the consumption-output ratio and the changes in macroeconomic aggregates. The money-output ratio and the money-wealth ratio are both lower in the model economy (2.4 percent in 1995 to 4.4 percent in 2002) than in the data (3.8 percent in 1995 to 5.1 percent 2002).

Nonetheless, there are certain aspects of the Chinese economy with which the model is not consistent. Notably, the model implied capital-output in 1995 and 2002 are 317 percent and 231 percent, respectively, while the same set of ratios, as calculated by data, were much lower in 1995 and 2002 at 231 percent and 286 percent. Meanwhile, investment-output ratios as implied by the model ( 35 percent in 1995 and 36 percent in 2002) were much lower than the data (58 percent in 1995 and 2002). The reason is that the discount rate of our model implies an approximately 4 percent real interest rate, which is lower than the actual rate; in turn, the model overestimates capital and underestimates investment relative to its empirical counterpart. 


\section{B. Counterfactual Experiments}

Given that our calibrated economy is reasonably consistent with the data from both 1995 and 2002, we perform a series of counterfactual experiments to isolate and then understand the effects of inflation, portfolio adjustment costs, borrowing constraints, fiscal policies, and income processes. In each of the counterfactual experiment, we first start with the 1995 data calibrated model, i.e., all parameters are calibrated with CHIPS 1995 and then change only one parameter of interest from its 1995 calibrated value to its 2002 calibrated value. Table 6 reproduces detailed aggregate statistics pertaining to the two calibrated economies (under column 1995 Calibrated Economy and column 2002 Calibrated Economy, respectively) and the counterfactual economies. 
Table 6: Counter-Factual Experiments --- Effect at the aggregate level

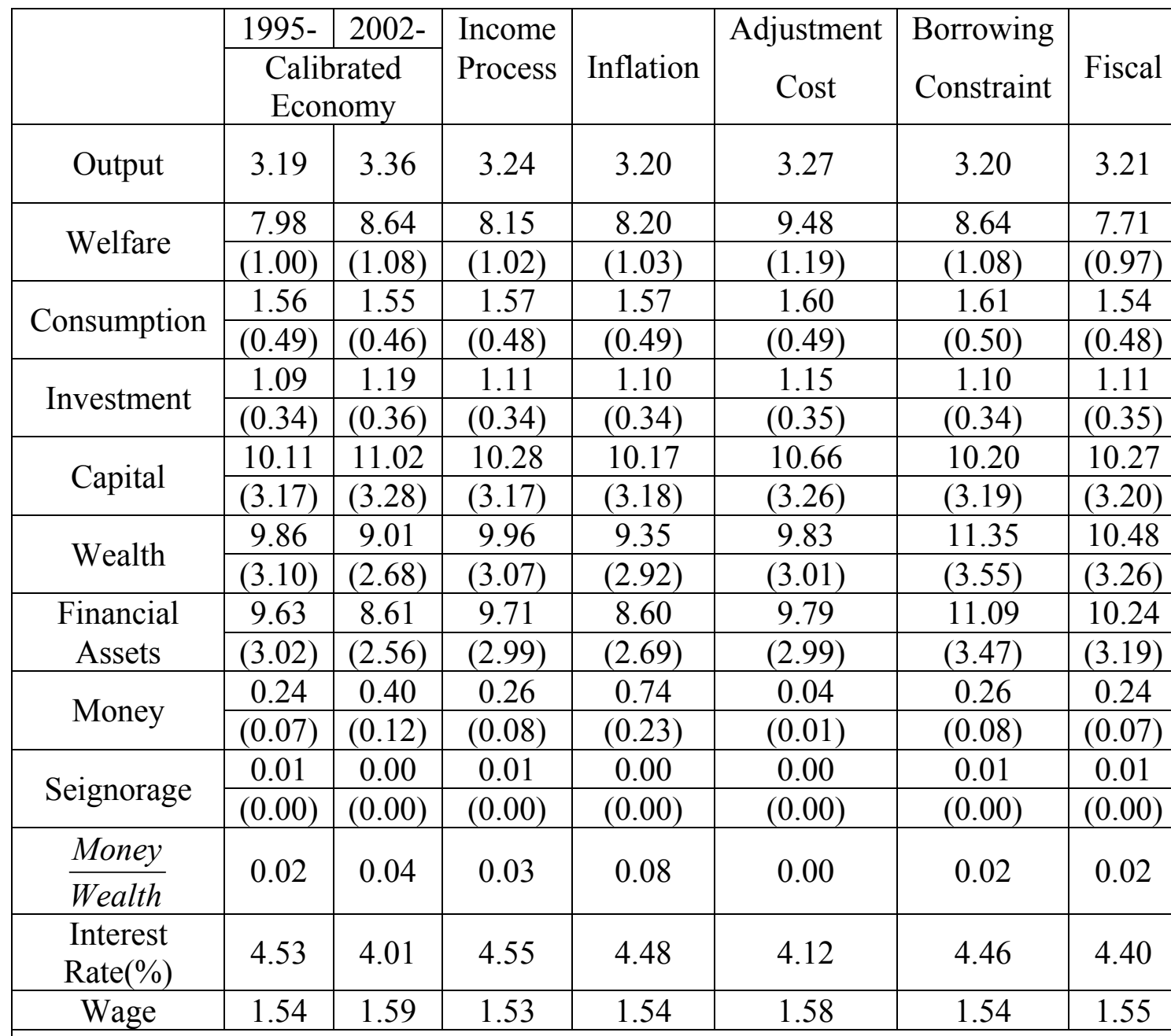

Note: Numbers in parenthesis is the ratio to output level of the variable in the respective experiment, except for Welfare. Welfare is calculated as the aggregated life-time utility of all households, as given by the utility function, and reported in absolute utility terms. Number in parenthesis in welfare is calculated by aggregating the life-time utility of each individual in the economy and then normalized by the level of aggregate welfare of the 1995-economy. Columns Income Process, Inflation, Adjustment Cost, Borrowing Constraint, and Fiscal report the result at the aggregate level of the counterfactual experiment that replace the 1995 calibrated income process, inflation, adjustment cost, borrowing constraint, and fiscal policy, by the 2002 calibrated value, respectively.

According to the table, the level of physical capital is larger than the level of aggregate financial assets in the 1995 Calibrated Economy and the 2002 Calibrated Economy. This observation implies that the government in the model economy has savings rather than debt in 1995 and 2002. This result is due to our calibration strategy for the government budget constraint. Because we have government expenditure and tax data for 1995 and 2002 but do 
not have data on government debts, we were able to calibrate only the tax and government expenditures. Our calibration of government expenditures and tax revenue led to a negative operational deficit (i.e., $T<G$ ). Recall that the government budget constraint at the stationary equilibrium is as follows:

$$
r B=T-G+\frac{\pi \bar{m}}{1+\pi} \text {. }
$$

Given that the seigniorage revenue cannot cover the operational deficit, the government debt $(B)$ must be negative. Such a value implies that the government has positive savings at equilibrium. Because the no-Ponzi game condition is imposed on the private sector and the government at the stationary equilibrium, the government must meet the perpetual outflows of current income (i.e., $T-G+\frac{\pi \bar{m}}{1+\pi}<0$ ) by receiving interest income from positive savings. This prediction is broadly consistent with the idea that the Chinese government has been investing in physical capital to promote economic growth because the channel of funding from households to physical capital is hindered by imperfections in the financial market.

At the disaggregate level, Figure 1 shows the wealth distributions and the Lorenz curve in the 1995 Calibrated Economy (in figures: 1995 economy; blue line) and in the 2002 Calibrated Economy (in figures: 2002 Economy; red line). The horizontal axis in both panels labels the amount of total wealth while the y-axis in the left panel (right panel) labels the proportion (cumulative proportion) of households holding the corresponding amount of total wealth. The figure shows that the wealth distribution in the 1995 Calibrated Economy is more dispersed than that in the 2002 Calibrated Economy since the red line is mostly above the blue line.

Figure 1: The wealth distribution and Lorenz Curve, 1995 Calibrated Economy Vs 2002 Calibrated Economy
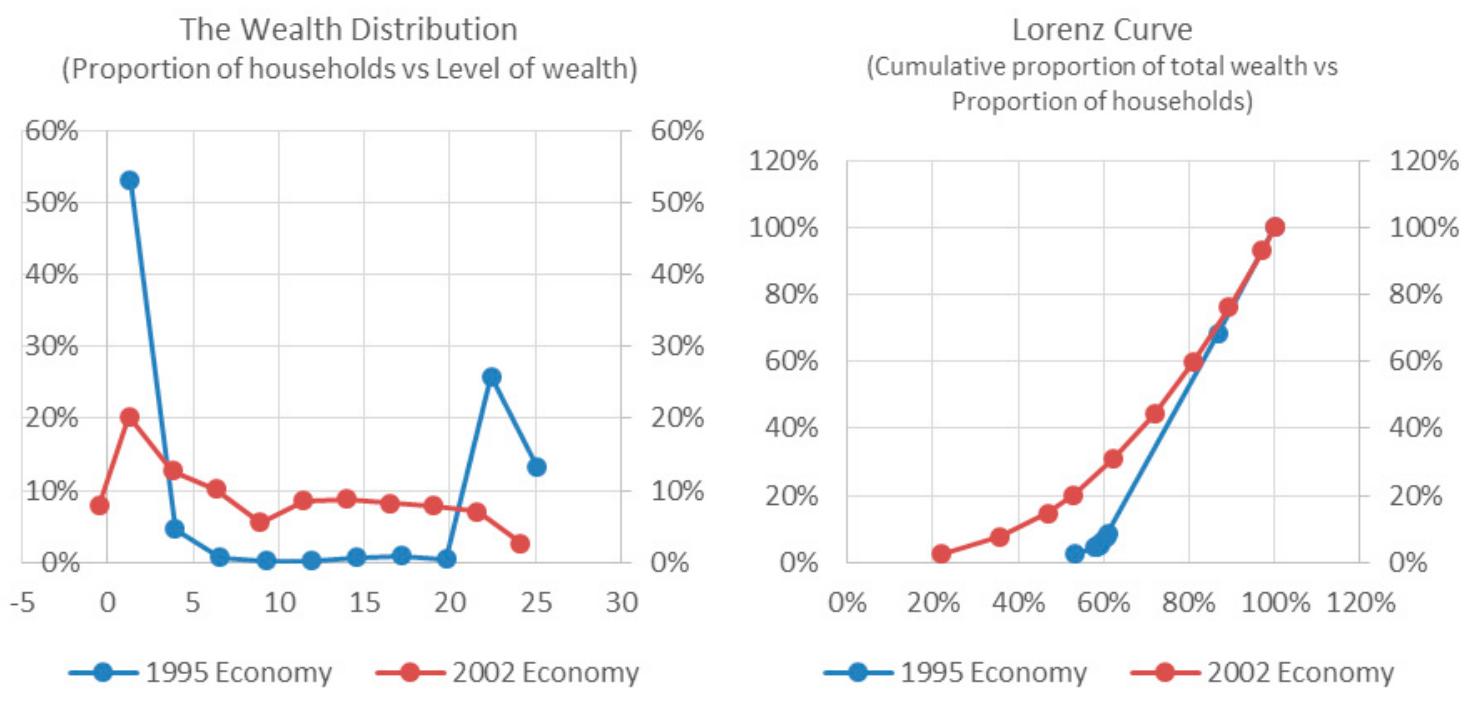
Figure 2 shows the financial assets holdings and the money holding of the 1995 Calibrated Economy and the 2002 Calibrated Economy. In the figure, the horizontal axis in both panels labels the amount of total wealth and the vertical axis label the amount of the financial assets holding (in the left panel) and money holding (in the right panel). Consistent with the observations in Figure 1, the figure suggests that the financial assets holding in the 2002 Calibrated Economy is held more equally across households than in the 1995 Calibrated Economy. Meanwhile, the money holding in the 2002 Calibrated Economy is also more spread out, in which poor households tend to hold a larger amount of money than in the 1995 Calibrated Economy.

Figure 2: Financial assets holding and money holding against level of wealth of households, 1995 Calibrated Economy vs 2002 Calibrated Economy
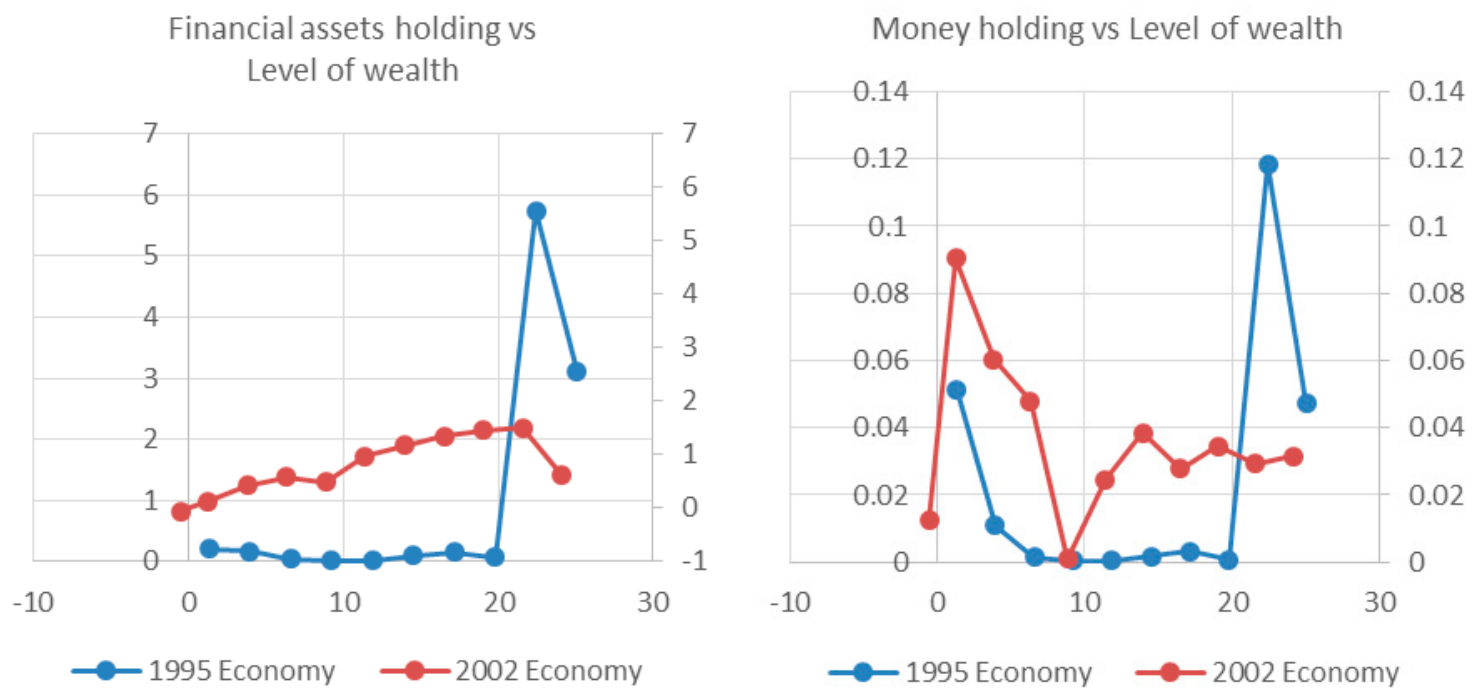

To quantify the degree of equality/inequality, Table 7 reports the Gini coefficient and the Coefficient of Variation of the resulting wealth distribution in each experiment.

Table 7: Counterfactual Experiments --- Effect on wealth distributions

\begin{tabular}{|l|l|l|l|l|l|l|l|}
\hline & $\begin{array}{l}1995 \\
\text { Calibrated } \\
\text { Economy }\end{array}$ & $\begin{array}{l}2002 \\
\text { Calibrated } \\
\text { Economy }\end{array}$ & $\begin{array}{l}\text { Income } \\
\text { Process }\end{array}$ & Inflation & $\begin{array}{l}\text { Adjustment } \\
\text { Cost }\end{array}$ & $\begin{array}{l}\text { Borrowing } \\
\text { Constraint }\end{array}$ & $\begin{array}{l}\text { Fiscal } \\
\text { Policy }\end{array}$ \\
\hline Gini & 0.57 & 0.43 & 0.53 & 0.59 & 0.44 & 0.46 & 0.53 \\
\hline CV & 1.10 & 0.84 & 0.96 & 1.15 & 0.77 & 0.95 & 1.02 \\
\hline
\end{tabular}

Note: Column 1995 calibrated Economy and 2002 calibrated Economy refer to the model calibrated with CHIPS1995 and CHIPS 2002, respectively. Column Income process, Inflation, Adjustment Cost, Borrowing Constraint, and Fiscal Policy refer to the counterfactual experiment, which we start with the 1995-economy but replace with the corresponding 2002 parameter value. Row Gini reports the Gini coefficient of the wealth distribution in each scenario labeled under each column. Row $C V$ reports the Coefficient of Variation of the wealth distribution in each scenario labeled under each column. 


\section{Changed Income Process}

It is well-known that the income process of an individual has important effect on the wealth distribution. As such, we begin the discussion of the counterfactual experiments by first understanding the implication of the change in the income dynamics between 1995 and 2002.

In this experiment, we replace the 1995 income process by the 2002 income process and keep other parameter values at their 1995 calibrated values. Recall that the estimated income process in 2002 is close to that in 1995, with only slightly increase in mean income and the persistence of income shock. Column Income Process in Table 6 shows that total wealth increases slightly at the aggregate level from 9.86 to 9.96 when the income process is changed to its 2002 value. Behind this is that financial assets and money holdings increase slightly and cause the aggregate money-wealth ratio to also increase slightly.

Figure 3 below shows both the wealth distribution and the Lorenz Curve obtained in the 1995 Calibrated Economy (label in figures: 1995 economy; blue line) and in this counter-factual experiment (label in figures: Changed Income Process; red line). As shown in the figure, the wealth distribution flattened (compare the blue line with the red line) slightly due to the change of the income process, which is now more persistent than before. Accordingly, as reported in Table 7, the Gini coefficient of the wealth distribution is decreased from 0.57 in 1995 Calibrated Economy to 0.53 in the Changed Income Process scenario.

Figure 3: The wealth distribution and Lorenz Curve, 1995 Calibrated Economy vs Changed Income Process
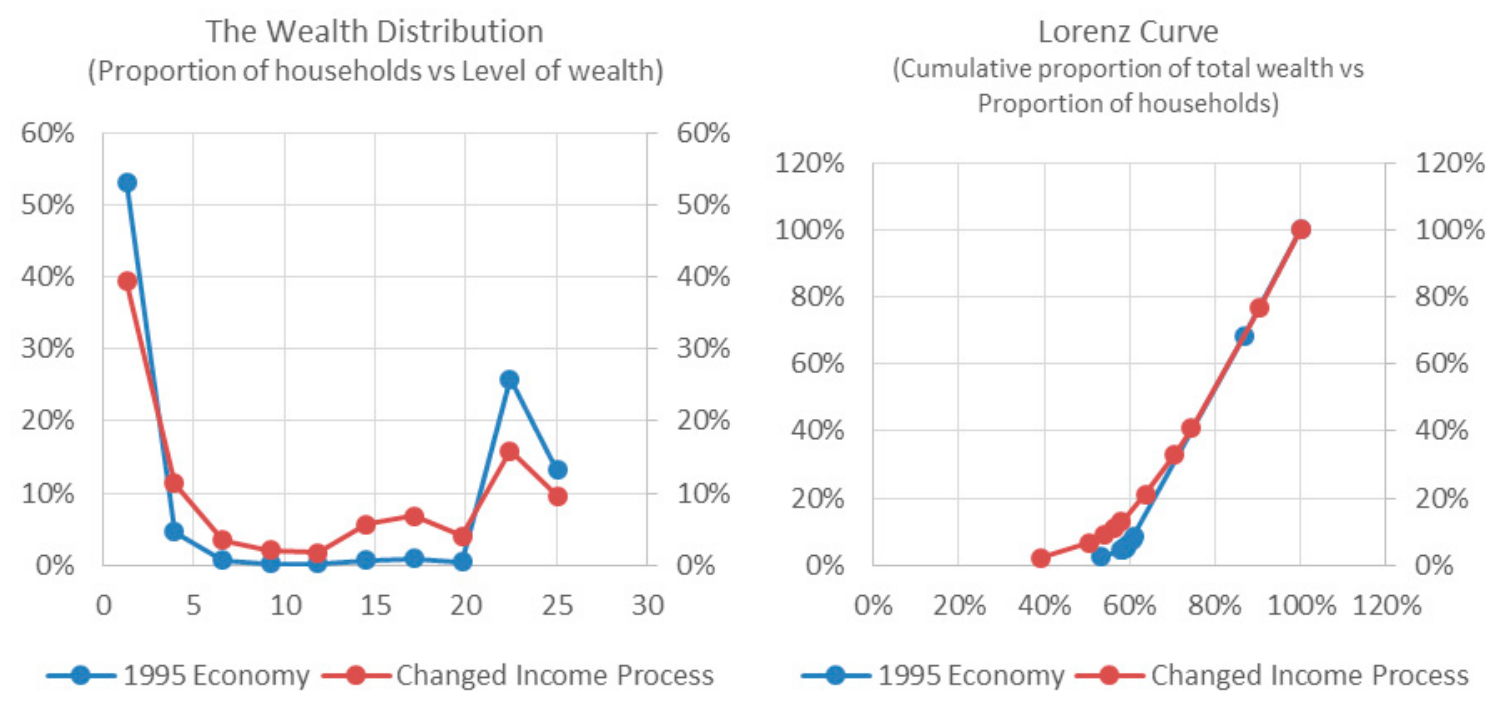

Figure 4 below shows the impact on the financial assets holding and money holding of various wealth groups changed due to the change of the income process. Comparing the blue lines and the red lines, we can see that the lower wealth households now hold slightly more 
financial assets and money when the income process has changed. This offsets the decline in the financial assets holding and the money holding in the higher wealth groups. This results in an increase in both the aggregate financial assets holding and money holding, and therefore, also an increase in aggregate total wealth.

Figure 4: Financial assets holding and money holding against level of wealth of households, 1995 Calibrated Economy vs Changed Income Process

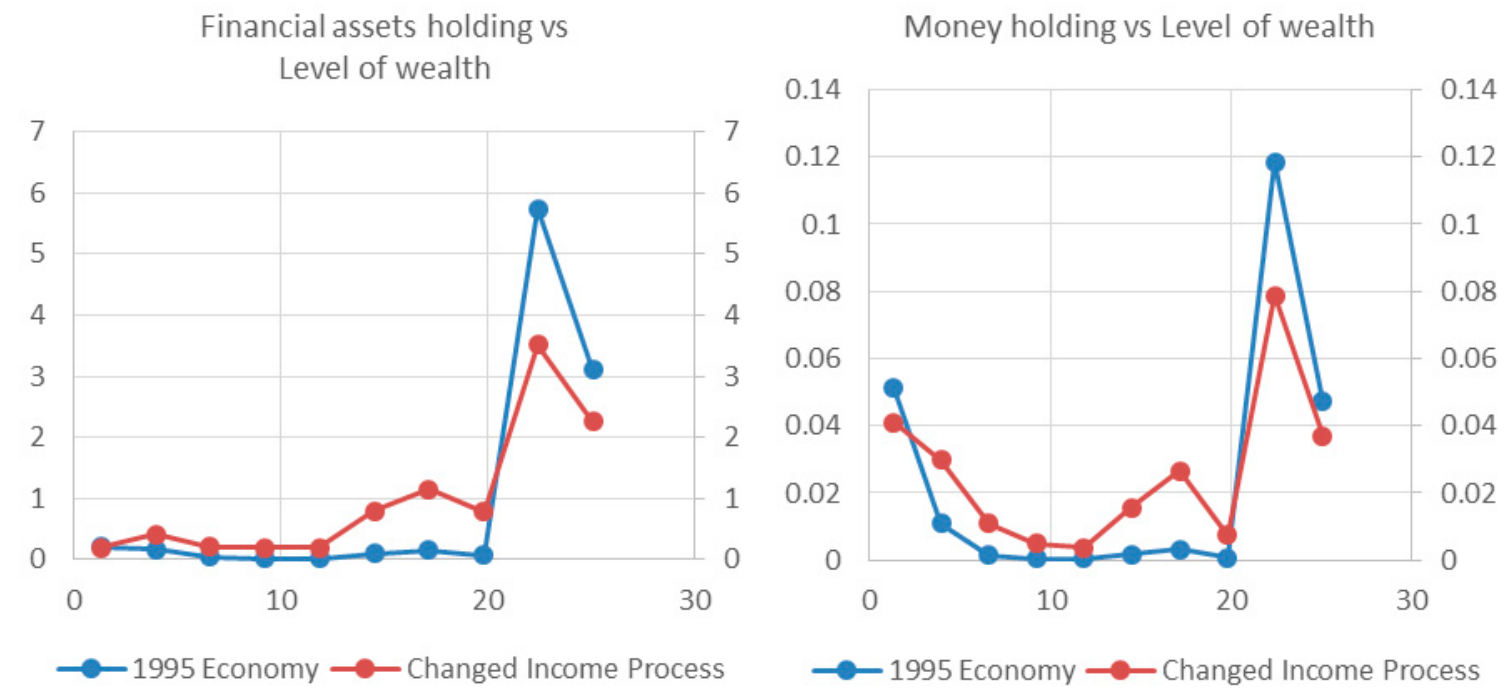

\section{Changed Inflation}

In this set of experiments, we replace the (six-year average) inflation in the 1995 economy with the (six-year average) 2002 value. The results are reported in column Inflation in Tables 6 and 7. Households raise their money holdings and reduce their financial assets when inflation decreases. These changes lead to lower wealth with higher aggregate money-wealth ratios. Because it is cheaper to hold money for precautionary saving, households are induced to lower their financial asset holdings as a result of the precautionary motive.

If more households hold a smaller amount of financial assets and wealth, then it may result in lower levels of financial assets and wealth at the aggregate level.

Nonetheless, our model also predicts that the aggregate capital increases and the real interest rate decreases as the inflation rate decreases; this prediction differs from the Tobin effect (see Tobin, 1965). The reason that our model predicts a different relationship between the levels of capital and inflation is related to our calibration strategy regarding government expenditures and tax. Although a decrease in the inflation rate increases the equilibrium quantity of money, seigniorage revenue decreases as a result of the large decrease in inflation. Because the calibrated operation deficit of the government is negative, the further declines in seigniorage revenue require the government to increase the amount of savings to generate sufficient interest income with which to maintain a balanced budget. As a result, the 
increase in government savings offsets the decrease in financial assets; therefore, the excess saving is used to increase the aggregate amount of physical capital as inflation decreases.

Figure 5 below shows both the wealth distribution and the Lorenz Curve obtained in the 1995 Calibrated Economy (labels in figures: 1995 economy; blue line) and in this counterfactual experiment (labels in figures: Changed Inflation; red line). As we can see from the figure, the wealth distribution and also the Lorenz curve in the 1995 Calibrated Economy and in the Changed Inflation experiment are very similar to each other. Accordingly, the Gini coefficient of the wealth distribution also only changed slightly.

Figure 5: The wealth distribution and Lorenz Curve, 1995 Calibrated Economy vs Changed Inflation
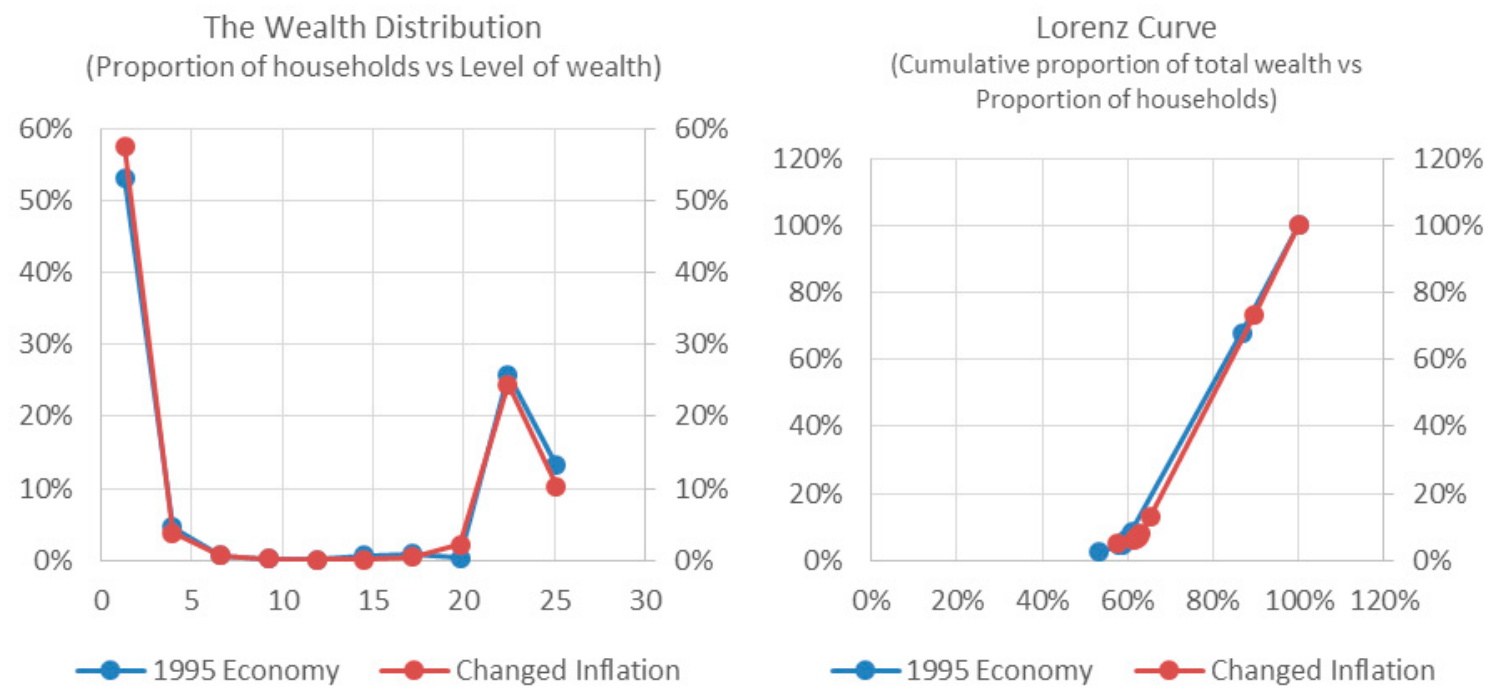

Figure 6 traces out the financial assets holding and money holding of households in different wealth groups under the 1995 Calibrated Economy and the Changed Inflation scenario. As we can see, the financial assets holding decreased very slightly, while the money holding of households increased rather significantly for poor and wealthy households when inflation is now much lower than before. 
Figure 6: Financial assets holding and money holding against level of wealth of households, 1995 Calibrated Economy vs Changed Inflation

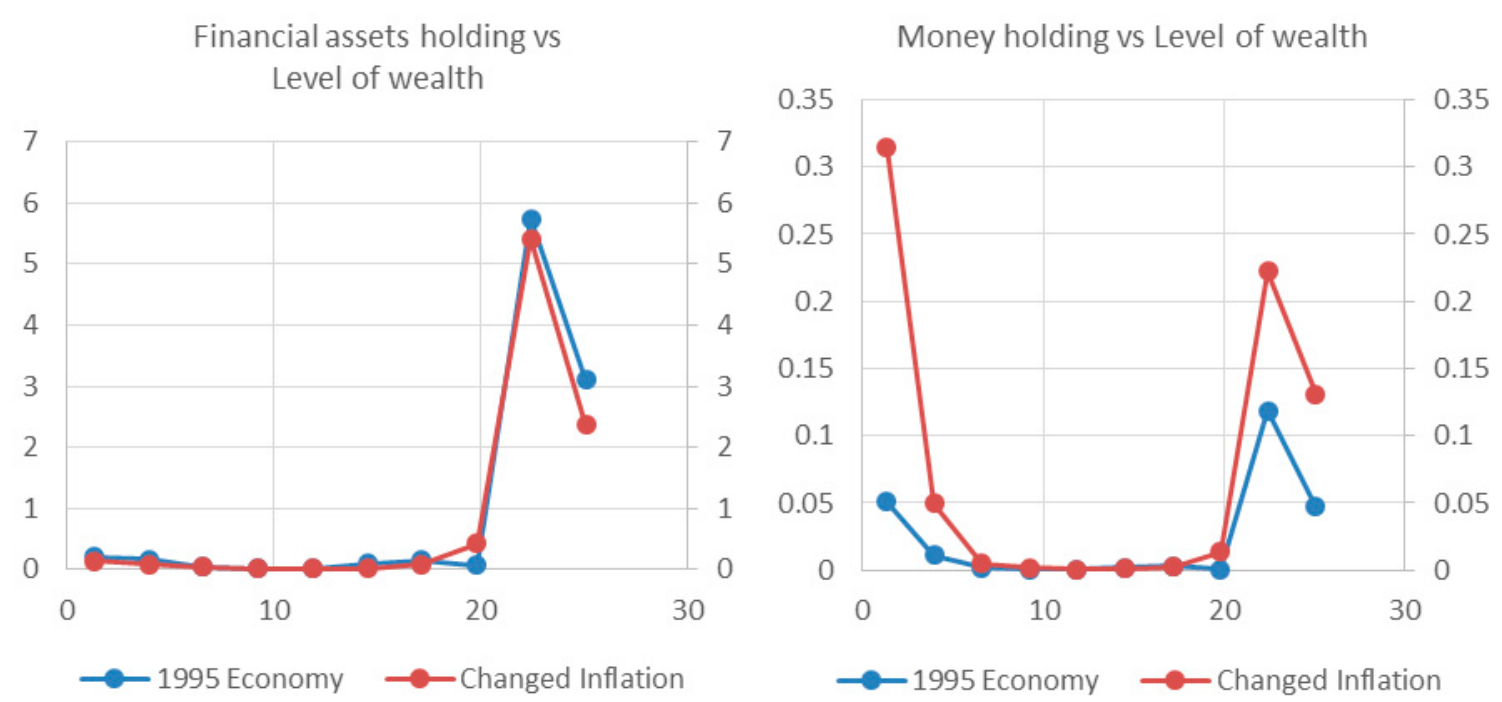

A decrease in inflation results in an increase in money holding and a decrease in the financial assets of households across wealth groups as households substitute money for financial assets for precautionary saving. Households with lower levels of wealth choose to increase their money holdings and decrease their financial asset holdings to a greater degree than those households with a higher level of wealth because the portfolio adjustment cost when measured by the marginal utility of consumption is higher for low-wealth households than for high-wealth households. Thus, a steady state with a lower inflation rate is associated with more households in the low-wealth group than a steady state with a higher inflation rate because these households are holding more money and fewer financial assets when the inflation rate is reduced. This situation also results in a more unequal financial asset distribution but a more equal money distribution.

\section{Changed Adjustment Cost}

In this experiment, we change the value of the portfolio adjustment cost from the 1995 calibrated value of 0.35 to the 2002 calibrated value of 0.1 and keep other parameters at their 1995 calibrated values. As the portfolio adjustment cost decreases, the aggregate demand of financial assets increases, while that of money decreases (see column Adjustment Cost in Table 6). ${ }^{17}$ This situation results in a slight decrease in aggregate wealth. As a result,

\footnotetext{
${ }^{17}$ We argue that this result is driven by the fact that, under the current calibration of the model, the positive wealth effect of interest rates on financial assets not only continue to dominate the negative wealth effect of the portfolio adjustment cost but by an even larger margin after the portfolio adjustment cost is lowered under this counter-factual experiment.
} 
the aggregate money-wealth ratio decreases; thus, this decrease indicates that the use of money for precautionary savings is less important. The aggregate consumption increases as the portfolio adjustment cost decreases.

Again, Figure 7 below shows both the wealth distribution and the Lorenz Curve obtained in the 1995 Calibrated Economy (label in figures: 1995 economy; blue line) and in the scenario of lower adjustment cost (labels in figures: Changed Adjustment Cost; blue line). The figure shows that the wealth distribution is flattened significantly. Correspondingly, the Gini coefficients of the wealth declined significantly from 0.57 in 1995 Calibrated Economy to 0.44 in Changed Adjustment Cost scenario. Specifically, there are now more households in the low-wealth group and fewer households in the high-wealth group compared with the 1995 Calibrated Economy. In addition, the low-wealth households now accumulate more wealth than before, whereas high-wealth households hold smaller amount of wealth than before; this situation results in a lower dispersion of wealth distribution.

Figure 7: The wealth distribution and Lorenz Curve, 1995 Calibrated Economy vs Changed Adjusted Cost
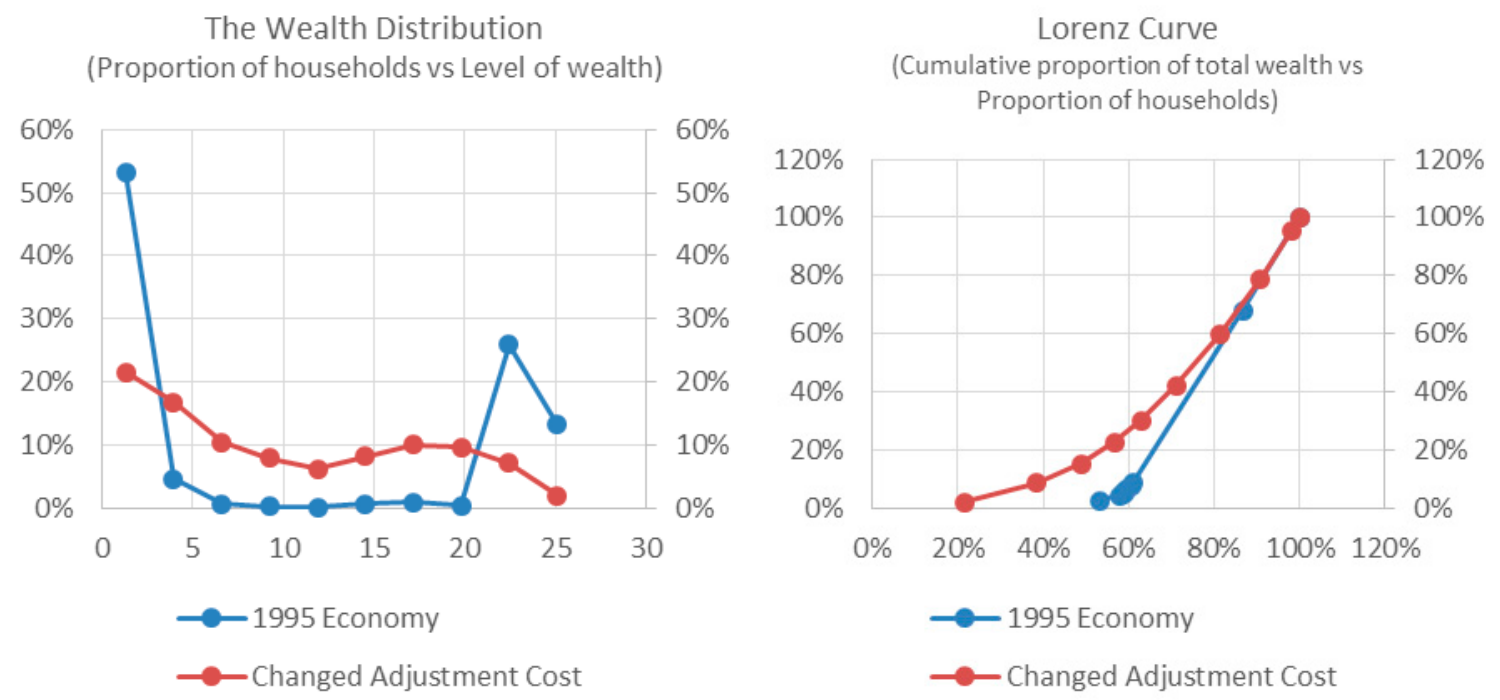

Examining the financial assets holding and money holding against the wealth of households in the two scenarios in Figure 8, reveals that when the adjustment cost is lowered, the lower wealth households tend to hold more financial assets but less money while the higher wealth 
households tend to hold fewer financial assets and also money.

Figure 8: Financial assets holding and money holding against level of wealth of households, 1995 Calibrated Economy vs Changed Adjusted Cost
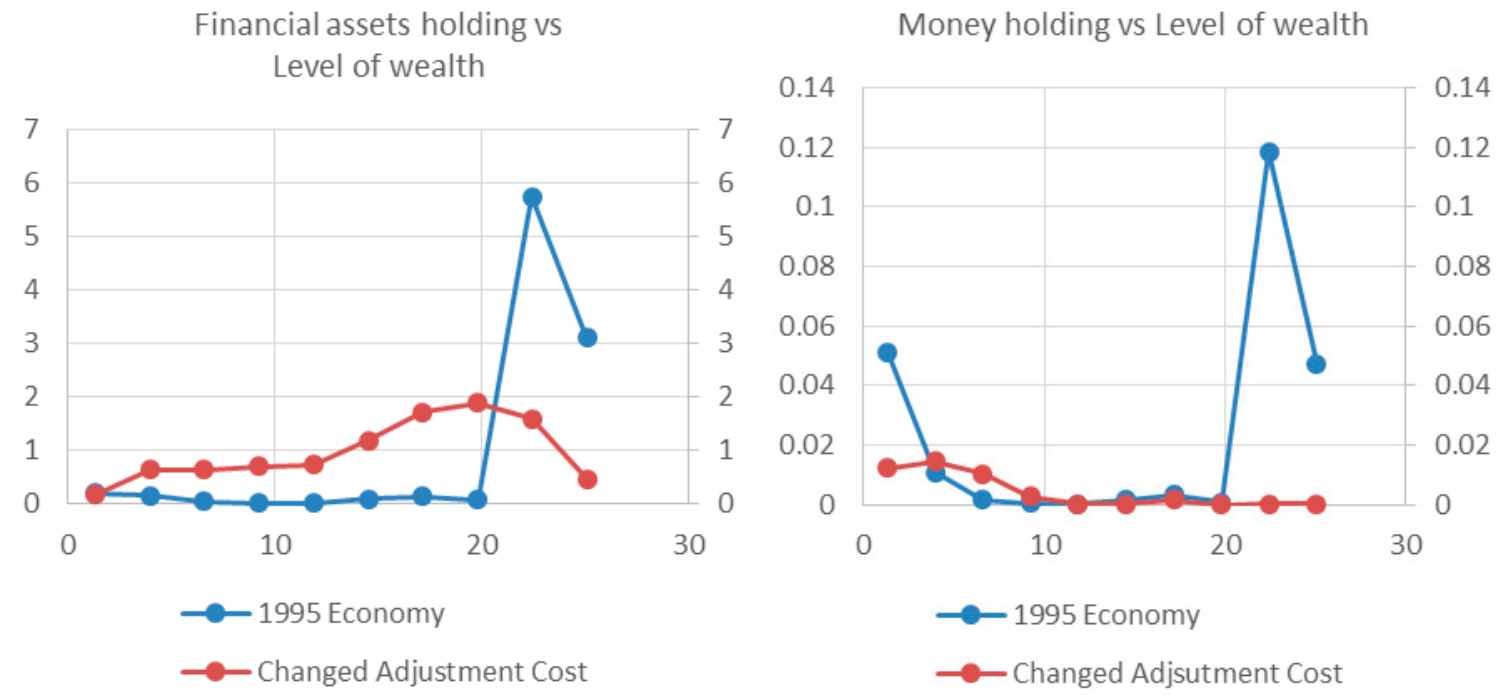

Because the portfolio adjustment cost is incurred when households adjust their financial assets, this cost affects both the incentives of households to accumulate financial assets and the cost of using financial assets to hedge income risks. In particular, the direct effect of a lower portfolio adjustment cost is to encourage households to accumulate financial assets. However, the lower portfolio adjustment cost also decreases the cost of using financial assets for precautionary savings (because it is less expensive to enter the financial market), and this decrease induces a lower level of savings. The direct channel becomes more pronounced for low-wealth households, and the indirect channel becomes more pronounced for high-wealth households because the portfolio adjustment cost decreases with household wealth in terms of the marginal utility of consumption. Consequently, in the steady state with a lower portfolio adjustment cost, those originally low- (high-) wealth households accumulate more (fewer) financial assets, which results in a higher (lower) population in the low- (high-) wealth group although those households have more (fewer) financial assets. Because financial assets are the main component of the wealth distribution, it makes wealth distribution more equal as a result.

\section{Changed Borrowing Constraint}

In this sub-section, we discuss the effect of changing the borrowing constraint and ensuring that other parameters remain at the 1995 calibrated values (see column Borrowing Constraint in Table 6). When the borrowing constraint is loosened, the aggregate wealth and financial assets increase, but the aggregate money and money-wealth ratio increased only 
insignificantly. Moreover, the relaxation of the borrowing constraint results in increased aggregate consumption.

As we can see from Figure 9 (1995 Economy; blue line for the 1995 Calibrated Economy and Changed Borrowing Constraint; red line for the relaxed borrowing constraint scenario), when the borrowing constraint is loosened and no longer completely binding, there are more wealthy households which hold more financial assets. Because the population of wealthy households increases by more than the amount of financial assets held by these households, this situation results in more equally distributed financial assets. When the credit constraint is loosened, poor households can smooth their consumption by borrowing, which induces a higher demand for financial assets. Therefore, a larger supply of financial assets is necessary to clear the market. Because of the presence of the portfolio adjustment cost, relatively wealthier households hold more financial assets (than required by the increased credit demand) to generate "extra" interest income to pay for the portfolio adjustment cost and economize on the cost of using the financial market. As a result, the aggregate financial assets increase.

Figure 9: The wealth distribution and Lorenz Curve, 1995 Calibrated Economy vs Changed Borrowing Constraint
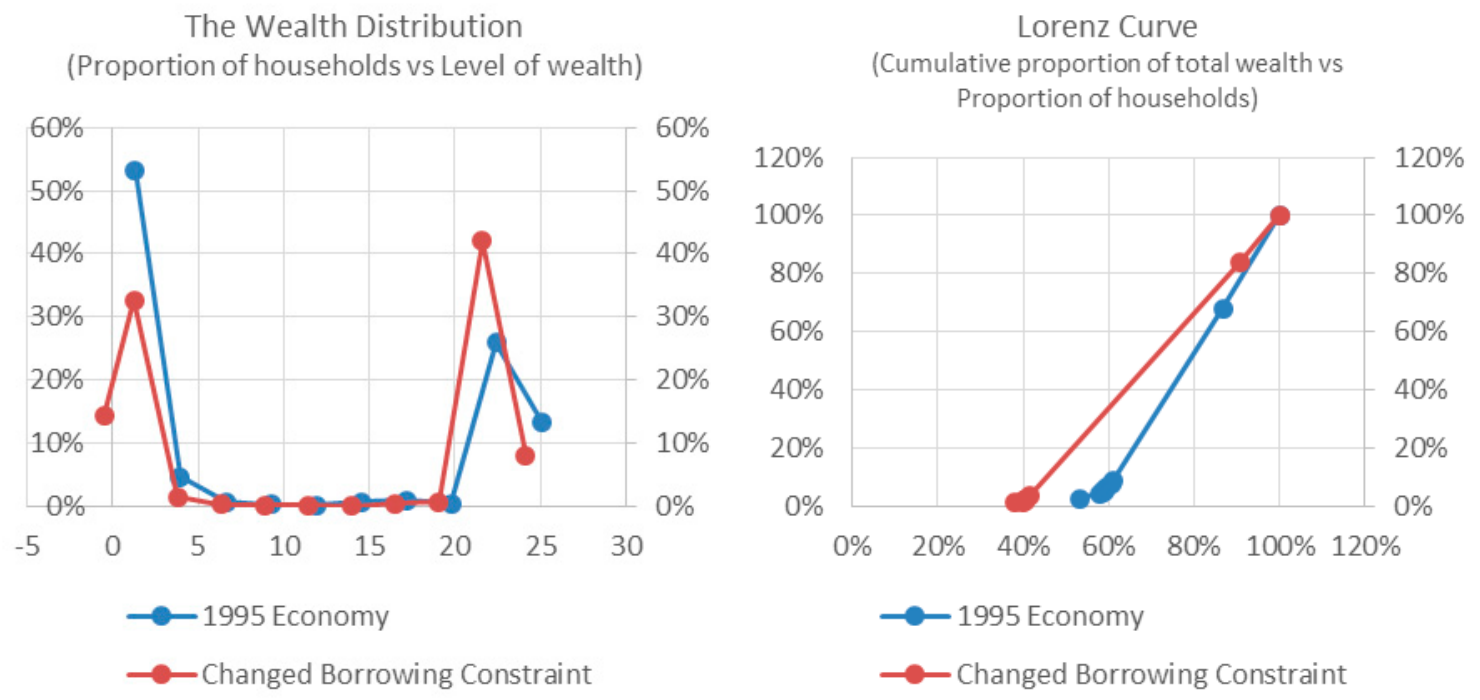

Meanwhile, Figure 10 shows that the money distribution becomes more concentrated because more wealthy households hold money and these households need to hold more money to smooth their consumption after investing in an illiquid financial assets account. The aggregate level and distribution of wealth mirror those of financial assets because financial assets have a dominant weight in household portfolios. 
Figure 10: Financial assets holding and money holding against level of wealth of households, 1995 Calibrated Economy vs Changed Borrowing Constraint

Financial assets holding vs

Level of wealth

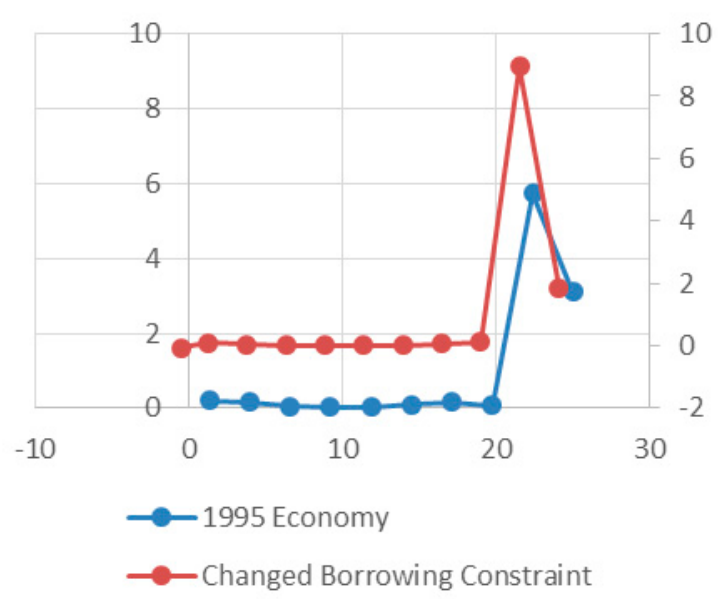

Money holding vs Level of wealth

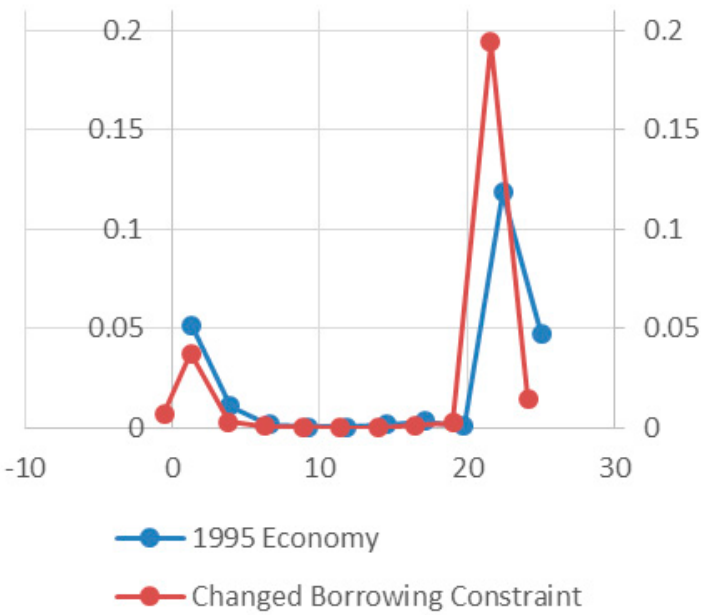

\section{Changed Fiscal Policy}

In this set of experiments, we replace the 1995 government expenditure to output ratio (14.7 percent) and tax to output ratios ( 25 percent) with those of the 2002 calibrated values, 17 percent and 28 percent, respectively and ensure that other parameters remain at their 1995 calibrated values. Both the government expenditure and tax to output ratios increase slightly from the 1995 calibration to the 2002 calibration. Column Fiscal Policy in Table 6 reports the corresponding results.

The households hold more wealth (from 9.86 to 10.48) with higher financial assets (from 9.63 to 10.24 ) and about the same amount of money holding at the aggregate level in this scenario. Household after-tax income decreases when taxes increase. When government expenditures increase, a higher level of capital is required to attain the same amount of private consumption. Therefore, a tax increase has a direct negative effect on wealth, but an increase in government expenditures encourages the economy to invest more to expand production opportunities to cover the increase in government spending and to increase capital and aggregate wealth.

The changes in fiscal policy do not significantly change the Gini coefficient of wealth distributions as showed in the wealth distribution and Lorenz curve in Figure 11 (1995 Economy; blue line for the 1995 Calibrated Economy and Changed Fiscal Policy; red line for the changed fiscal policy scenario). 
Figure 11: The wealth distribution and Lorenz Curve, 1995 Calibrated Economy vs Changed Fiscal Policy

The Wealth Distribution

(Proportion of households vs Level of wealth)

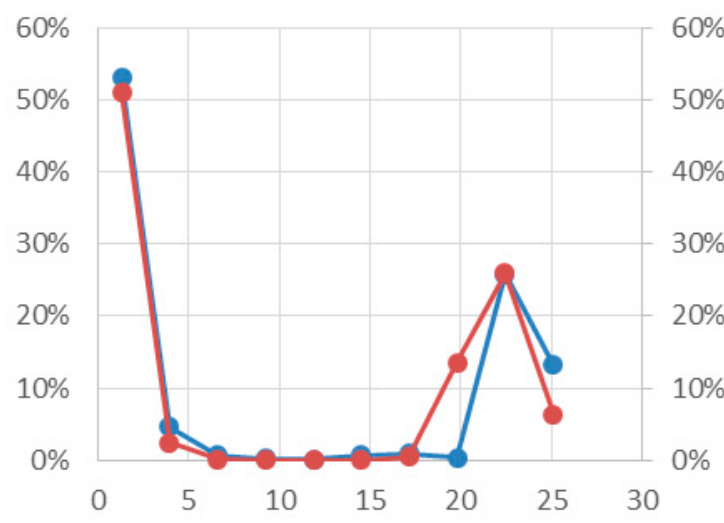

$\longrightarrow 1995$ Economy $\longrightarrow$ Changed Fiscal Policy
Lorenz Curve

(Cumulative proportion of total wealth vs Proportion of households)

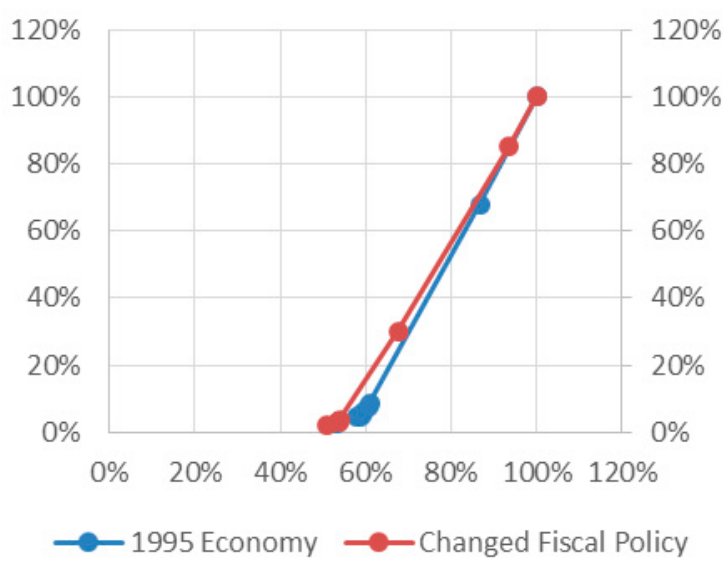

The financial asset holding and money holding also exhibit similar changes as showed in Figure 12. Although the relative size of the high-wealth group increases, the share of financial assets that they hold does not increase proportionally. As a result, there is almost no change in the Gini coefficients of wealth, financial assets, and money.

Figure 12: Financial assets holding and money holding against level of wealth of households, 1995 Calibrated Economy vs Changed Fiscal Policy

Financial assets holding vs Level of wealth

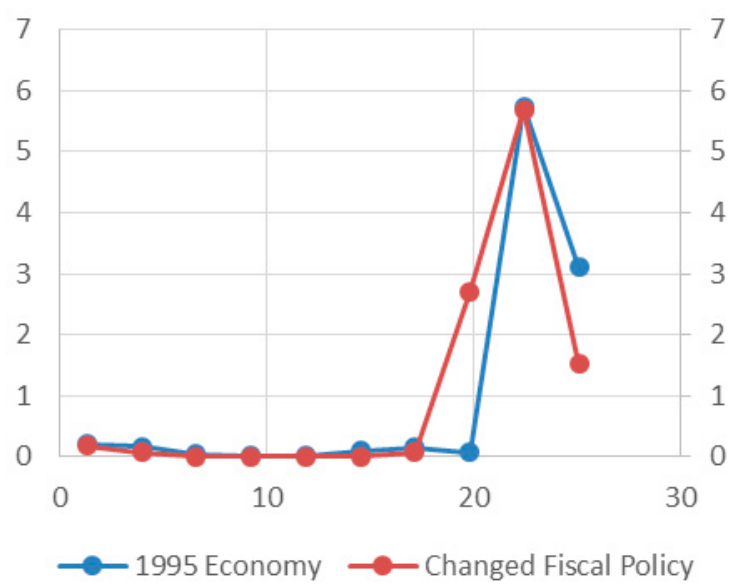

Money holding vs Level of wealth

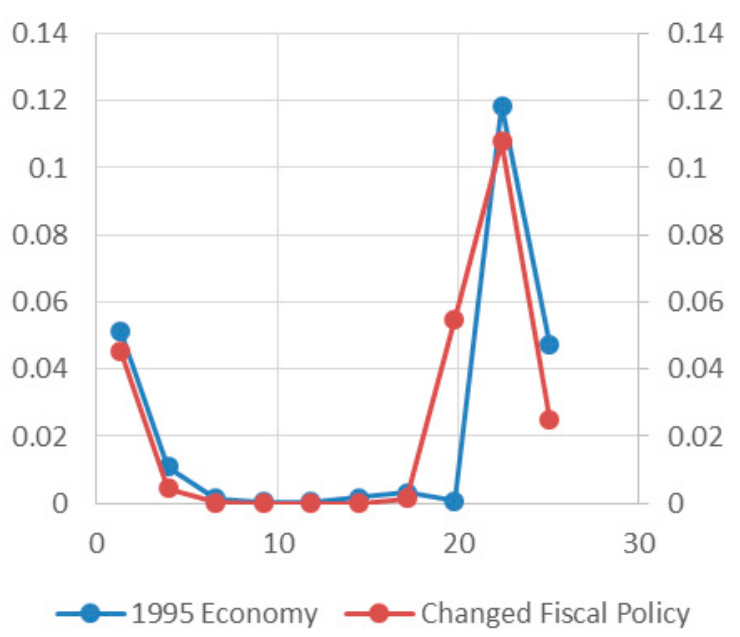




\section{Accounting for Changes and Welfare Analysis}

In the previous sub-sections, we analyzed the effects of income process, inflation, portfolio adjustment costs, borrowing constraints, and fiscal policies on changes in wealth distribution and macroeconomic aggregates. We summarize these effects to investigate their quantitative importance in explaining the empirical patterns in Table 8 below. 
Table 8: Accounting changes from 1995 to 2002

\begin{tabular}{|c|c|c|c|c|c|c|}
\hline & $\begin{array}{l}2002- \\
\text { Economy }\end{array}$ & Inflation & $\begin{array}{l}\text { Adjustment } \\
\text { Cost }\end{array}$ & $\begin{array}{l}\text { Borrowing } \\
\text { Constraint }\end{array}$ & Fiscal & $\begin{array}{l}\text { Income } \\
\text { Process }\end{array}$ \\
\hline Output & 0.17 & 0.01 & 0.08 & 0.01 & 0.03 & 0.06 \\
\hline \multirow[b]{2}{*}{ Welfare } & 0.66 & 0.22 & 1.50 & 0.66 & -0.26 & 0.17 \\
\hline & $(0.08)$ & $(0.03)$ & $(0.19)$ & $(0.08)$ & $(-0.03)$ & $(0.02)$ \\
\hline \multirow{2}{*}{ Consumption } & -0.01 & 0.00 & 0.04 & 0.05 & $\begin{array}{l}-0.02 \\
\end{array}$ & 0.01 \\
\hline & $(-0.03)$ & $(0.00)$ & $(0.00)$ & $(0.01)$ & $(-0.01)$ & $(-0.01)$ \\
\hline \multirow{2}{*}{ Investment } & 0.10 & 0.01 & 0.06 & 0.01 & 0.02 & 0.02 \\
\hline & $(0.01)$ & $(0.00)$ & $(0.01)$ & $(0.00)$ & $(0.00)$ & $(0.00)$ \\
\hline \multirow{2}{*}{ Capital } & 0.91 & 0.07 & 0.55 & 0.09 & 0.17 & 0.18 \\
\hline & $(0.11)$ & $(0.01)$ & $(0.09)$ & $(0.01)$ & $(0.03)$ & $(0.00)$ \\
\hline \multirow{2}{*}{ Wealth } & -0.86 & -0.52 & -0.04 & 1.49 & 0.61 & 0.10 \\
\hline & $(-0.41)$ & $(-0.17)$ & $(-0.09)$ & $(0.45)$ & $(0.17)$ & $(-0.03)$ \\
\hline \multirow{2}{*}{$\begin{array}{l}\text { Financial } \\
\text { Assets }\end{array}$} & -1.02 & -1.02 & 0.16 & 1.46 & 0.61 & 0.08 \\
\hline & $(-0.46)$ & $(-0.33)$ & $(-0.03)$ & $(0.44)$ & $(0.17)$ & $(-0.03)$ \\
\hline \multirow{2}{*}{ Money } & 0.16 & 0.51 & -0.19 & 0.03 & 0.00 & 0.02 \\
\hline & $(0.04)$ & $(0.16)$ & $(-0.06)$ & $(0.01)$ & $(0.00)$ & $(0.00)$ \\
\hline \multirow{2}{*}{ Seignorage } & -0.01 & -0.01 & -0.01 & 0.00 & 0.00 & 0.00 \\
\hline & $(0.00)$ & $(0.00)$ & $(0.00)$ & $(0.00)$ & $(0.00)$ & $(0.00)$ \\
\hline$\frac{\text { Money }}{\text { Wealth }}$ & 0.02 & 0.06 & -0.02 & 0.00 & 0.00 & 0.00 \\
\hline Interest Rate (\%) & $-0.52 \%$ & $-0.05 \%$ & $-0.41 \%$ & $-0.07 \%$ & $-0.13 \%$ & $0.02 \%$ \\
\hline Wage & 0.05 & 0.00 & 0.04 & 0.01 & 0.01 & 0.00 \\
\hline
\end{tabular}

As the table shows, the portfolio adjustment cost and the borrowing constraint are the largest two factors that help make the wealth distribution more equal, in terms of the Gini coefficients - the portfolio adjustment cost alone can reduce the Gini coefficient from 0.57 to 0.44 while the borrowing constraint itself can reduce the Gini coefficient from 0.57 to 0.46 .

With regard to the money-output ratio and the money-wealth ratio, there are two significant offsetting forces: inflation, which increases the money-output ratio from 0.24 to 0.74 and the money-wealth ratio from 0.02 to 0.08 , and the portfolio adjustment cost, which reduces the money-output ratio from 0.24 to 0.04 and the money-wealth ratio from 0.02 to about 0 . 
The welfare improved by 8 percent from 1995 to 2002 . The counterfactual experiments show that the reduction in the portfolio adjustment cost, from 0.35 to 0.1 , is the strongest single factor to improve the welfare - it can improve the welfare by 19 percent by itself. The relaxation of the borrowing constraint, from virtually zero to -1 alone could improve the welfare gain by 8 percent. The reduction in inflation, from 12 percent to nearly zero percent alone will increase the welfare by 3 percent. The change of the income process itself could improve the welfare by 2 percent. The only offsetting force in welfare from 1995 to 2002 is the change in fiscal policy (increasing both the government expenditure to output ratio from 14 percent to 17 percent and the tax to output ratio from 25 percent to 27 percent), which along will reduce the welfare by three percent. The increase in tax and government expenditures substantially offsets the welfare gain arising from the other factors. ${ }^{18}$

\section{Conclusion}

This paper presents a dynamic general equilibrium model with money, heterogeneous agents, and an incomplete financial market. We introduce financial development in terms of depth and accessibility into the model and find that such development has asymmetric effects on households with different portfolio compositions. We calibrate the model with Chinese data and show that this model reproduces key stylized facts. Despite the simplicity of our model, it offers useful insights into the recent Chinese experience. Tighter monetary policies in the late 1990s increased the value of money, and this increase led to a higher money-output ratio, a higher money-wealth ratio, and a tighter money distribution across households. Improvements in the depth and accessibility of the financial market reduced the precautionary motive of households, which induced more equal wealth and financial asset distributions.

Finally, our paper provides several policy implications. Our results suggest that lowering access barriers to the financial market and deepening the financial market can greatly improve the welfare, especially for the wealth-poor households. It is because lowering the barrier to using the financial market (both to invest and to borrow) allows households to hold fewer liquid assets, which are usually subject to higher inflation tax and hence reduces the dispersion of wealth distribution. In addition to a deeper financial system, an increase in access to financial services, especially in rural and underserved areas, reduces the dispersion of wealth distribution by depressing the reliance on money and hence decreasing the moneywealth ratio.

\footnotetext{
${ }^{18}$ Due to the non-linearity presented in the model, the sum of the welfare change of all individual factors does not need to sum to the overall improvement in the welfare between 1995 and 2002.
} 


\section{APPENDIX I - COMPUTATION OF THE MODEL}

The model is solved by the method of Value Function Iteration over a discretized three dimensional state space (over labor productivity, money, and financial assets). The labor productivity is discretized according to the method mentioned in Section 3 in the main text. The money holding and financial assets are discretized into 60 and 80 points. To improve the accuracy of the solution without compromising the computation speed heavily, we allow the households to chose next period's money and financial asset from a finer grid that consists of 360 and 480 points, respectively. We have checked the robustness of our results against the density of grid points and find that the current results do not significantly differ from those calculated based on an even finer grids.

For a given inflation rate, $\pi$, tax rate and government expenditure, we initialize the computation by "guessing" a value of aggregate capital and calculate the corresponding real interest rate and wage. In step 2, we solve the household's dynamic programing problem according to Equation (4) with the real interest rate and wage at each point in the state space. In step 3, we then calculate the stationary distribution of households, upon having the policy functions of consumption, money holdings for the next period and financial assets for the next period from step 3 . In step 4, we use the resulting stationary distribution of households to calculate the aggregate money holding, aggregate consumption and aggregate financial assets of households. We then check if the aggregate constraint is satisfied at the solution. If not, we update our guess of aggregate capital and restart from step 2 to step 4 and repeat until the aggregate constraint is satisfied (at the solution, the difference of aggregate capital across two consecutive loops is also insignificant).

\section{APPENDIX II- DATE DESCRIPTION}

This section describes the details and characteristics of the data used to calibrate our model. We focus on income and wealth composition in this discussion. The sources of data are the Chinese Household Income Projects (CHIPS) from 1995 and 2002. The data were collected through surveys in 11 provinces, which include Beijing, Shanxi, Liaoning, Jiangsu, Anhui, Henan, Hubei, Guangdong, Chongqing, Sichuan, Yunnan, and Gansu, by the Institute of Economics, Chinese Academy of Social Sciences, in 1995 and 2002. The surveys for those two years are consistent with one another regarding the income, wealth, and demographic information of household members. Hence, these surveys provide sufficient information with which to study changes in household conditions, such as income (Démurger et al., 2006) and wealth (Meng, 2007).

A salient feature of our data is that we observe wealth at the household level in addition to the data on income dynamics. The information regarding total wealth consists of financial wealth, durable goods, assets used for productive purposes, housing wealth, and other assets. Within the financial wealth data, there is information regarding term deposits, current 
deposits, bonds, stocks, personal lending, personal wealth used for family productive purposes, accumulated amounts of housing funds, and other investments. Moreover, we have information regarding households' total liabilities, which is composed of mortgages, borrowing for productive uses, buying household durables, medical-related debt, and other debt resulting from family difficulties.

Table A1 reports the household characteristics of these two surveys. In both samples, 96 percent of the respondents are of the majority race (Han). More male respondents are in the later sample. The average age of the respondents increases from 42.6 in the earlier sample to 45.0 in the later sample. Similarly, the number of years of education completed increases slightly from 10.3 in the earlier sample to 10.8 in the later sample, and the proportion of married people increases from 91 percent to 93 percent between the two samples. Finally, more respondents (from 27 percent to 30 percent) are members of the Communist Party in the later sample. Table A1 suggests that individuals in these two samples are largely comparable to one another and provide a reasonable basis for comparative study.

Table A1: Households Characteristics

\begin{tabular}{|l|l|l|}
\hline & CHIPS 1995 & CHIPS 2002 \\
\hline Male & 0.5 & 0.52 \\
\hline Age & 42.6 & 45 \\
\hline School Year & 10.3 & 10.8 \\
\hline $\begin{array}{l}\text { Majority } \\
\text { (Hans) }\end{array}$ & 0.96 & 0.96 \\
\hline Married & 0.91 & 0.93 \\
\hline $\begin{array}{l}\text { Communist } \\
\text { Party }\end{array}$ & 0.27 & 0.3 \\
\hline $\begin{array}{l}\text { Number of } \\
\text { Observations }\end{array}$ & 12648 & 12558 \\
\hline
\end{tabular}

We deflate the total income to 1990 prices using the regional specific price deflators for urban areas developed by Brandt and Holz (2006). We use the spatial price deflator rather than the official consumer price index (CPI) because the official CPI does not allow for interprovincial price differentials. We believe that it is important to control spatial price differences in a country with large geographical coverage and substantial variation in regional economic development. Brandt and Holz (2006) estimate the differences in the costs of living among provinces and between urban and rural areas. They employ the raw regional price data for 1990 to compute the cost of living indices across provinces for that year. The 1990 spatial price indices are then extrapolated to later years using provincial urban and rural CPIs. However, there is a caveat for using the spatial price deflators in our application. Because the raw price data with which to construct the spatial deflator were only available for 1990, the spatial deflators for years following 1990 are obtained by extrapolation. The accuracy of the extrapolations deteriorates over time because the consumption basket and the quality of goods and services consumed change over time. Nonetheless, the spatial deflator 
provides an improvement over the official CPI to correct for spatial price differences. Démurger et al. (2006) show that income equality that is computed based on the spatial deflator is smaller than what is computed based on the official CPI.

Table A2 provides the descriptive statistics pertaining to income over the sample period. First, annual income increased from RMB 2,624 in 1990 to RMB 4,787 in 2002. Second, the dispersions of income remain stable within each sample, but the dispersion becomes larger in the later sample. This point is consistently confirmed by the coefficient of variation and the Gini coefficient.

Table A2: Descriptive Statistics on reported incomes: CHIPS 1995 and CHIPS 2002

\begin{tabular}{|l|l|l|l|l|l|l|l|}
\hline \multicolumn{2}{|l|}{ CHIPS 1995 } & \multicolumn{2}{l|}{ CHIPS 2002 } \\
\hline Year & $\begin{array}{l}\text { Mean } \\
{[\text { SD }]}\end{array}$ & CV & Gini & Year & $\begin{array}{l}\text { Mean } \\
{[\text { SD }]}\end{array}$ & CV & Gini \\
\hline 1990 & $\begin{array}{l}2624 \\
{[1408]}\end{array}$ & 0.54 & 0.27 & & & & \\
\hline 1991 & $\begin{array}{l}2884 \\
{[1562]}\end{array}$ & 0.54 & 0.27 & 1998 & $\begin{array}{l}3509 \\
{[2285]}\end{array}$ & 0.62 & 0.30 \\
\hline 1992 & $\begin{array}{l}3148 \\
{[1721]}\end{array}$ & 0.55 & 0.26 & 1999 & $\begin{array}{l}3688 \\
{[2127]}\end{array}$ & 0.58 & 0.29 \\
\hline 1993 & $\begin{array}{l}3424 \\
{[1696]}\end{array}$ & 0.50 & 0.25 & 2000 & $\begin{array}{l}4014 \\
{[2296]}\end{array}$ & 0.57 & 0.29 \\
\hline 1994 & $\begin{array}{l}3502 \\
{[1696]}\end{array}$ & 0.49 & 0.25 & 2001 & $\begin{array}{l}4288 \\
{[2471]}\end{array}$ & 0.58 & 0.30 \\
\hline 1995 & $\begin{array}{l}3601 \\
{[1835]}\end{array}$ & 0.51 & 0.27 & 2002 & $\begin{array}{l}4787 \\
{[2913]}\end{array}$ & 0.61 & 0.31 \\
\hline
\end{tabular}

Note: $C V$ denotes coefficient of variation; The numbers of observation are 12648 and 12558 for the CHIPS 1995 and CHIPS 2002, respectively. The values are at 1990 prices (unit in $R M B)$.

We deflate household wealth with the same deflator that was used for income and report the descriptive statistics in Table A3. The average money holding is approximately RMB 696 in 1995 and increases three-fold to RMB 2,076. The standard deviation of the money distribution does not change dramatically. The coefficient of variation decreases slightly from 1.98 in 1995 to 1.96 in 2002 . However, the Gini coefficient decreases from 0.75 to 0.69. The financial asset distribution changes more significantly across the two sample periods. Although the average financial assets increase by approximately the same factor as in the case of money holding (from RMB 13,553 to RMB 49,558), the changes in the coefficient of variations and the Gini coefficients are larger than the changes in money. In particular, the Gini coefficient decreases from 0.59 in 1995 to 0.44 in 2002. 
Table A3: Descriptive Statistics on Wealth distribution in 1995 and 2002

\begin{tabular}{|l|l|l|l|l|l|l|}
\hline \multicolumn{3}{|l|}{ CHIPS 1995 } & \multicolumn{3}{l|}{ CHIPS 2002 } \\
\hline & Mean [SD] & CV & Gini & Mean [SD] & CV & Gini \\
\hline Money & $656[1299]$ & 1.98 & 0.75 & $\begin{array}{l}2076 \\
{[4073]}\end{array}$ & 1.96 & 0.69 \\
\hline $\begin{array}{l}\text { Financial } \\
\text { Assets }\end{array}$ & 13553 & 1.28 & 0.59 & $\begin{array}{l}49558 \\
{[42762]}\end{array}$ & 0.86 & 0.44 \\
\hline Wealth & $147337]$ & & 0.58 & $\begin{array}{l}51634 \\
{[44162]}\end{array}$ & 0.86 & 0.43 \\
\hline
\end{tabular}

Note: $C V$ denotes coefficient of variation; The numbers of observation are 6862 and 6699 for the CHIPS 1995 and CHIPS 2002, respectively. The values are at 1990 prices (unit in $R M B)$.

Total wealth increases over time from RMB 14,209 in 1990 to RMB 51,634 in 2002. Total wealth increases more than the increases in income observed during the same period. According to the coefficient of variation and the Gini coefficient, the dispersion of wealth distribution is lower in 2002. Because a major portion of total wealth is financial assets, it is not surprising to find that the wealth distribution resembles the financial asset distribution. The sample wealth distributions based on CHIPS 1995 and CHIPS 2002 are plotted in the upper panel of figure A1 and A2, respectively. The lower panel of the two figures show the corresponding wealth composition. The two figures indicate that the shares of money in household portfolios decrease with the wealth of these households. As households become wealthier, their portfolios are more biased toward financial assets, which bear higher rates of return. This result is consistent with the evidence reported by Kennickell and Starr-McCluer (1997) for the United States. Furthermore, most households (except for those with extremely low or high levels of wealth) were likely to reduce the percentage of money in their wealth over the period from 1995 to 2002. The weaker money demand over time suggests that households may have a lower precautionary need of money and a lower transaction cost in converting financial assets to money. 
Figure A1: CHIPS 1995 Sample Wealth Distribution and Wealth Compositon

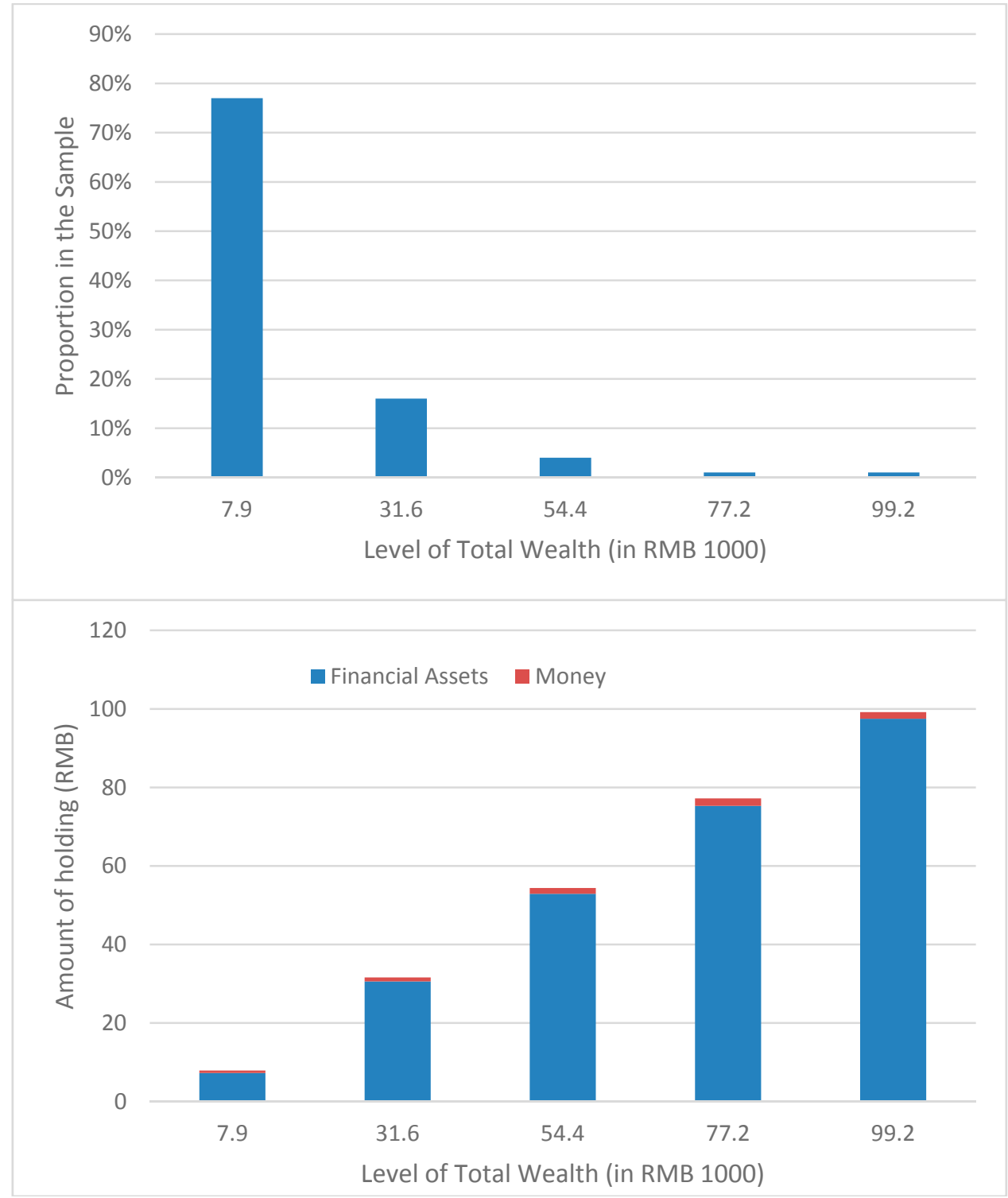


Figure A2: CHIPS 2002 Sample Wealth Distribution and Wealth Composition

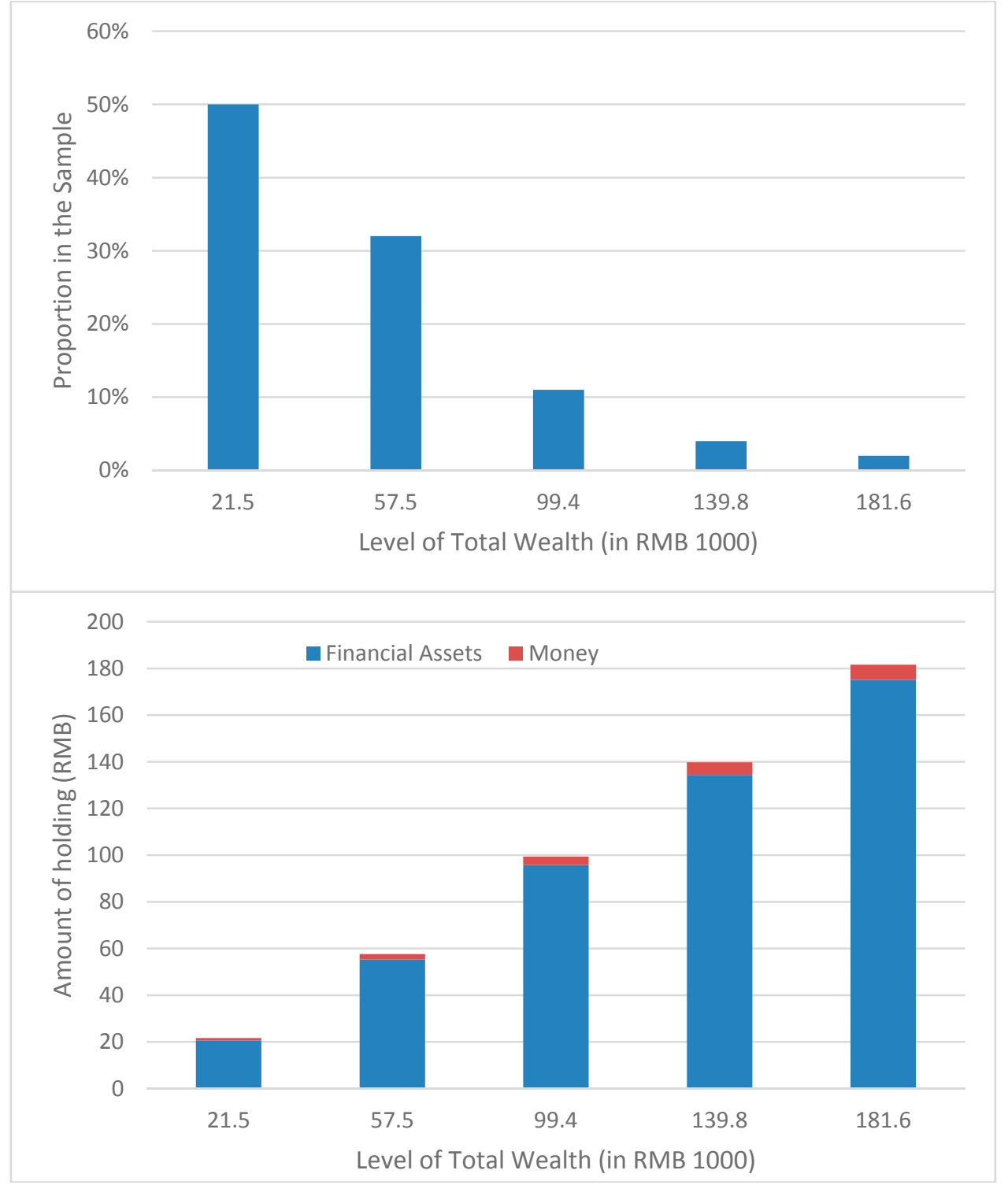




\section{REFERENCES}

Aiyagari, S. R. August 1994. "Uninsured Idiosyncratic Risk and Aggregate Saving." The Quarterly Journal of Economics 109 (3): 659-884.

Akyol, A. September 2004. "Optimal Monetary Policy in an Economy with Incomplete Markets and Idiosyncratic Risk.” Journal of Monetary Economics 51 (6): 1245-1269.

Albanesi, S. May 2007. "Inflation and Inequality.” Journal of Monetary Economics 54 (4): $1088-1114$.

Alvarez, F., A. Atkeson, and P.J. Kehoe. February 2002. "Money, Interest Rates, and Exchange Rates with Endogenously Segmented Markets." The Journal of Political Economy 110 (1): 73-112.

Amato, J. and S. Gerlach. May 2002. "Inflation Targeting in Emerging Market and Transition Economies: Lessons After a Decade.” European Economic Review 46 (4-5): 781-790.

Arellano, M. and S.R. Bond. April 1991. "Some Specification Tests for Panel Data: Monte Carlo Evidence and an Application to Employment Equations." Review of Economic Studies 58 (2): 277-297.

Bai, C, C. Hsieh, and Y. Qian. 2006. "The Return to Capital in China." Brookings Papers on Economic Activity 2006 (2): 61-88.

Beck, T, A. Demirgüç-Kunt, and P. Honohan. February 2009. "Access to Financial Services: Measurement, Impact, and Policies.” World Bank Research Observer 24: 119-145.

Beck, T, A. Demirgüç-Kunt, and R. Levine. March 2007. "Finance, Inequality and the Poor." Journal of Economic Growth 12: 27-49.

Blundell, R and S.R. Bond. November 1998. "Initial Conditions and Moment Restrictions in Dynamic Panel Data Models.” Journal of Econometrics 87 (1):115-144.

Blundell, R and S.R. Bond. November 2000. "GMM Estimation with Persistent Panel Data: An Application to Production Functions.” Econometric Reviews 19 (3): 321-340.

Brandt, L. and C. A. Holz. October 2006. "Spatial Price Differences in China: Estimates and Implications." Economic Development and Cultural Change 55 (1): 43- 86. 
Chatterjee, S. and D. Corbae. June 1992."Endogenous Market Participation and the General Equilibrium Value of Money." The Journal of Political Economy 100 (3): 615-646.

Démurger, S., M. Fournier, and S. Li. December 2006. "Urban Income Inequality in China Revisited (1988-2002).” Economics Letters 93 (3): 354-359.

Díaz, A. and M. J. Luengo-Prado. February 2010. "The Wealth Distribution with Durable Goods." International Economic Review 51 (1): 143-170.

Easterly, W. and S. Fischer, "Inflation and the Poor." Journal of Money, Credit and Banking, May 2001, 33 (2), 160-178.

Erosa, A. and G. J. Ventura, "On Inflation as a Regressive Consumption Tax.” Journal of Monetary Economics, May 2002, 49 (4), 761-795.

Goodfriend, M. and E. Prasad. 2007. "A Framework for Independent Monetary Policy in China." CESifo Economic Studies 53 (1): 2-41.

Heaton, J. and D.J. Lucas. June 1996. "Evaluating the Effects of Incomplete Markets on Risk Sharing and Asset Pricing." The Journal of Political Economy 104 (3): 443-487.

Heer, B. and B. Süssmuth. January 2007. "Effects of Inflation on Wealth Distribution: Do Stock Market Participation Fees and Capital Income Taxation Matter?" Journal of Economic Dynamics and Control 31 (1): 277-303.

Kennickell, A.B. and M. Starr-McCluer. December 1997. "Household Saving and Portfolio Change: Evidence from the 1983-89 SCF Panel." Review of Income and Wealth 43 (4): 381-399.

Khor, N. and J. Pencavel. June 2010. "Evolution of Income Mobility in the People's Republic of China: 1991-2002.” ADB Economics Working Paper Series 204, Asian Development Bank.

King, R.G. and R. Levine. August 1993. "Finance and Growth: Schumpeter Might Be Right." The Quarterly Journal of Economics 108 (3): 717-737.

Kopecky, K. A. and R. M.H. Suen. July 2010. "Finite State Markov-Chain Approximations to Highly Persistent Processes." Review of Economic Dynamics 13 (3), 701-714.

Meng, Xi. July 2007. "Wealth Accumulation and Distribution in Urban China." Economic Development and Cultural Change 55 (4): 761-791. 
Romer, C. and D. Romer. 1999. "Monetary Policy and the Wellbeing of the Poor." Economic Review, Federal Reserve Bank of Kansas City, First Quarter 1999: 21-49.

Rouwenhorst, G. 1995. "Asset Pricing Implications of Equilibrium Business Cycle Models." In Thomas F. C. (ed.), Frontiers of Business Cycle Research, Princeton University Press: 294-330.

Shen, B. and L. Yan. September 2009. "Development of Consumer Credit in China." In Bank for International Settlements ( ed.), Household Debt: Implications for Monetary Policy and Financial Stability, Vol. 46 of BIS Papers chapters, Bank for International Settlements: 51-57.

Tauchen, G. March 1986. "Finite State Markov-Chain Approximations to Univariate and Vector Autoregressions.” Economics Letters 20 (2): 177-181.

Tauchen, G. and Robert H. May 1991. "Quadrature-Based Methods for Obtaining Approximate Solutions to Nonlinear Asset Pricing Models.” Econometrica 59 (2): 371396.

Tobin, J. October 1965. "Money and Economic Growth.” Econometrica 33 (4): 671- 684.

Wolff, E. December 2006. "Changes in Household Wealth in the 1980s and 1990s in the United States.” In Edward N. Wolff, (ed.), International Perspectives on Household Wealth, Edward Elgar Publishing: 107-150. 